GABRIELE BIN ALVES PEREIRA

Imunodetecção de antígenos de Escherichia coli em infecção experimental em aves 
GABRIELE BIN ALVES PEREIRA

\title{
Imunodetecção de antígenos de Escherichia coli em infecção experimental em aves
}

\begin{abstract}
Dissertação apresentada ao Programa de Pós-Graduação em Patologia Experimental e Comparada da Faculdade de Medicina Veterinária e Zootecnia da Universidade de São Paulo para a obtenção do título de Mestre em Ciências
\end{abstract}

Departamento:

Patologia

Área de concentração:

Patologia Experimental e Comparada

Orientador:

Prof. Dr. Antonio José Piantino Ferreira

São Paulo 
Autorizo a reprodução parcial ou total desta obra, para fins acadêmicos, desde que citada a fonte.

\section{BIBLIOTECA VIRGINE BUFF D'APICE \\ FACULDADE DE MEDICINA VETERINÁRIA \\ E ZOOTECNIÃ DA USP \\ $21 / 11 / 12 \#$}

\section{DADOS INTERNACIONAIS DE CATALOGAÇÃO-NA-PUBLICAÇÃO}

(Biblioteca Virginie Buff D’Ápice da Faculdade de Medicina Veterinária e Zootecnia da Universidade de São Paulo)

Pereira, Gabriele Bin Alves

Imunodetecção de antígenos de Escherichia coli em infecção experimental em aves / Gabriele Bin Alves Pereira. -- 2012.

$64 \mathrm{f.}:$ il.

Dissertação (Mestrado) - Universidade de São Paulo. Faculdade de Medicina Veterinária e Zootecnia. Departamento de Patologia, São Paulo, 2012.

Programa de Pós-Graduação: Patologia Experimental e Comparada.

Área de concentração: Patologia Experimental e Comparada.

Orientador: Prof. Dr. Antonio José Piantino Ferreira.

1. Proteínas. 2. Escherichia coli. 3. Western blot. 4. Eletroforese unidimensional. I. Título. 


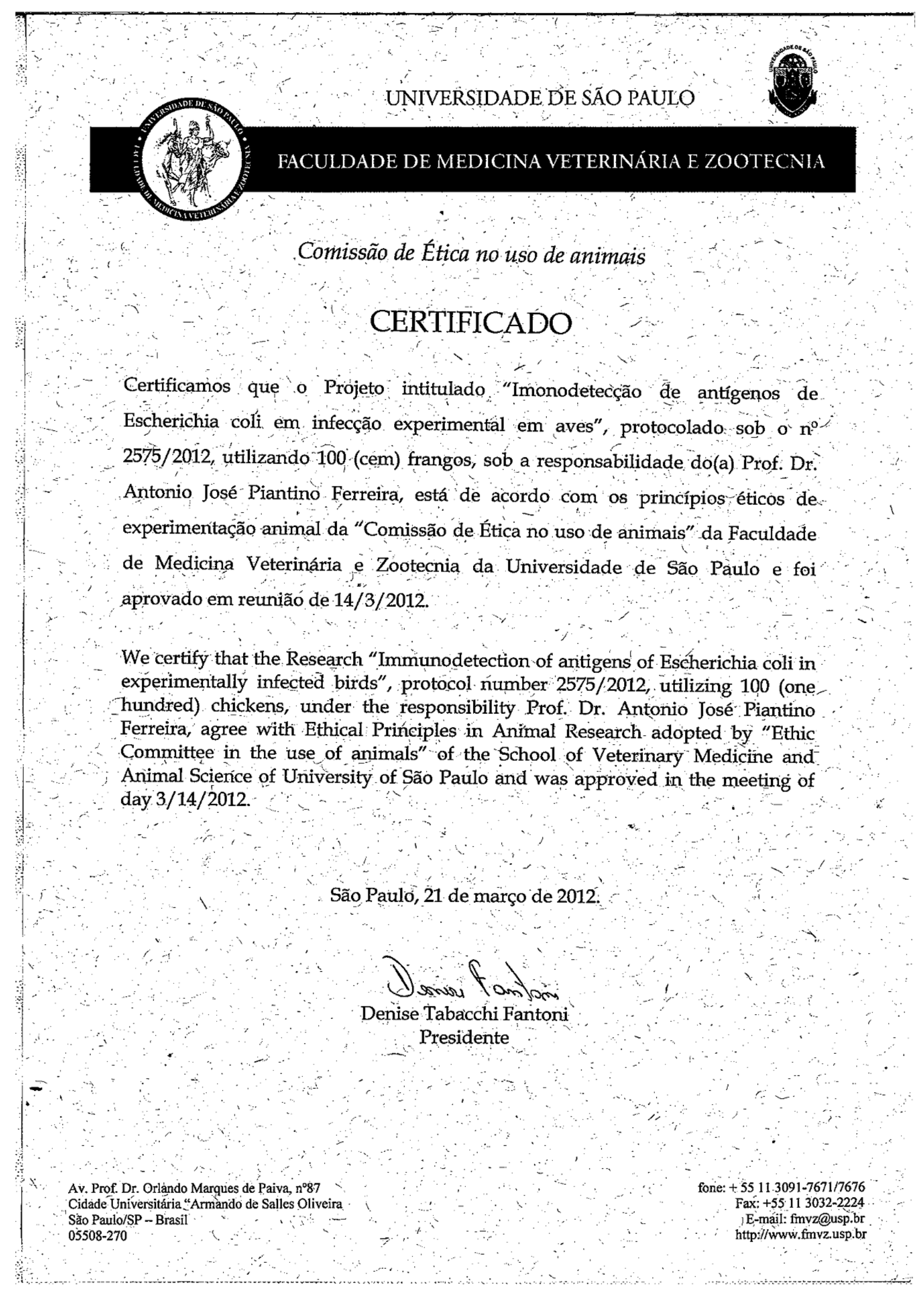




\section{FOLHA DE AVALIAÇÃO}

Nome: PEREIRA, Gabriele Bin Alves.

Título: Imunodetecção de antígenos de Escherichia coli em infecção experimental em aves.

Data:

Dissertação apresentada ao Programa de Pós-Graduação em Patologia Experimental

e Comparada da Faculdade de Medicina Veterinária e Zootecnia da Universidade de São Paulo para a obtenção do título de Mestre em Ciências

Banca Examinadora

Prof. Dr.

Instituição: Julgamento:

Prof. Dr.

Instituição: Julgamento:

Prof. Dr.

Instituição: Julgamento: 


\section{DEDICATÓRIA}

Dedico este trabalho primeiramente à minha mãe, que sempre acreditou na minha capacidade e sonhou meus sonhos comigo, sempre que você me diz que eu sou guerreira, eu acredito mais em mim, mas na verdade nas minhas alegrias e tristezas você sempre esteve ao meu lado com seu sorriso mais bonito, mesmo quando eu te acordava as 3h00 toda segunda-feira durante dois anos. Só posso dizer obrigada e que sou uma pessoa de muita sorte por ter uma mãe tão maravilhosa.

Dedico ao meu noivo José Diego, obrigada pelo apoio que você sempre me deu, sem nunca me dizer "não vá" e sim "vá com cuidado". Muito obrigada por ser meu amigo de todas as horas, com você ao meu lado todas as dificuldades ficaram menores. Ver como você é esforçado, me ajudou a seguir adiante.

À minha irmã Giovanna que apesar da distância, esteve por perto.

Dedico ao meu pai que a seu modo acompanhou meus passos e acreditou na minha capacidade. Seu apoio também foi fundamental para que eu atingisse meus objetivos. 


\section{AGRADECIMENTOS}

Agradeço ao Prof. Dr. Antonio José Piantino Ferreira pelo apoio, oportunidade e conhecimento dividido,

À Claudete por compartilhar toda a sabedoria na rotina do laboratório, pelo carinho, preocupação e paciência,

Aos meus companheiros de laboratório pela amizade e pelos momentos agradáveis no bandejão: Silvana, Maurício, Dennis, Luis, Big Lu, Little Lu, Joelma e Márcia.

Agradeço especialmente à Maria Eugênia, minha dupla inseparável, pela amizade em todos os momentos.

À Prof. Lilian pela oportunidade de ser aluna PAE,

A todos os professores que tive em tantos anos de estudo, pois muitas coisas que aprendi, eu agradeço aos mestres que me ensinaram.

A todos que de alguma forma contribuíram para que este trabalho fosse possível. 
Cada um que passa em nossa vida passa sozinho, pois cada pessoa é única, e nenhuma substitui outra. Cada um que passa em nossa vida passa sozinho, mas não vai só, nem nos deixa sós. Leva um pouco de nós mesmos, deixa um pouco de si mesmo. Há os que levam muito; mas não há os que não levam nada. Há os que deixam muito; mas não há os que não deixam nada. Esta é a maior responsabilidade de nossa vida e a prova evidente que nada é ao acaso. 


\section{RESUMO}

PEREIRA, G. B. A. Imunodetecção de antígenos de Escherichia coli em infecção experimental em aves. [Imunodetection of Escherichia coli antigens in experimental infection in broiler flocks]. 2012. 64f. Dissertação (Mestrado em Ciências) - Faculdade de Medicina Veterinária e Zootecnia, Universidade de São Paulo, São Paulo, 2012.

A colibacilose é uma enfermidade importante na avicultura por causar prejuízos econômicos e danos à carcaça. Escherichia coli é um micro-organismo oportunista e a complexidade da infecção se deve a diversidade de sorotipos, variados fatores de virulência e baixa capacidade de estimular a imunidade cruzada. Assim, a compreensão dos mecanismos de virulência que ocorrem no hospedeiro, pode resultar no desenvolvimento de métodos diagnósticos e profiláticos. Neste estudo, 85 pintinhos foram divididos em quatro grupos, sendo três infectados com diferentes sorogrupos de Escherichia coli (O2, O78, O119) e um vacinado com Poulvac ${ }^{\circledR}$ E.coli $\left(\right.$ Pfizer $\left.^{\circledR}\right)$. As lesões sugestivas de colibacilose foram avaliadas e qualificadas aos 35 dias de idade, e em seguida realizada a colheita de sangue para a obtenção do soro. Foram obtidas proteínas in vitro dos sorogrupos de E. coli utilizados na infecção experimental e da vacina (mutante de Escherichia coli O78). Estas foram separadas por eletroforese unidimensional em gel de acrilamida utilizando dodecil sulfato de sódio (SDS) e foram submetidas a reação de western blot com a mistura de soros de cada grupo estudado e também com o pool de soros de aves livres de patógenos específicos (SPF), usadas como controle negativo. O perfil eletroforético revelou a presença de várias proteínas dos diferentes sorogrupos de E. coli quando cultivadas no meio casaminoácido e levedura. Houve diferenças entre os sorotipos, mas também proteínas comuns. Foi possível estabelecer uma relação entre virulência, quantidades de proteínas específicas e taxa de reisolamento.

Palavras-chave: Proteínas. Escherichia coli. Western blot. Eletroforese unidimensional. 


\begin{abstract}
PEREIRA, G. B. A. Imunodetection of Escherichia coli antigens in experimental infection in broiler flocks. [Imunodetecção de antígenos de Escherichia coli em infecção experimental em aves]. 2012. 64f. Dissertação (Mestrado em Ciências) - Faculdade de Medicina Veterinária e Zootecnia, Universidade de São Paulo, São Paulo, 2012.

The colibacillosis is a serious disease in poultry industry to cause economic losses and damage to carcass. Escherichia coli is an opportunistic microorganism and the complexity of infection is due to the diversity of serotypes, several virulence factors and low ability to stimulate cross-immunity. Thus understanding of virulence mechanisms that occur in the host, may result in development of diagnostic and prophylactic methods. In this study, 85 chicks were divided into four groups being infected with three different serogroups of E. coli $(\mathrm{O} 2, \mathrm{O} 78, \mathrm{O} 119)$ and vaccinated with Poulvac E. coli ${ }^{\circledR}$ (Pfizer $\left.{ }^{\circledR}\right)$. The lesions suggestive of colibacillosis were evaluated at 35 days of age, and then the blood sample are collected to obtain the serum. Proteins were obtained in vitro from serogroups of E. coli used in experimental infection and vaccine (mutant of Escherichia coli O78). These were separated by one-dimensional electrophoresis on acrylamide gels using sodium dodecyl sulfate (SDS) and then reacted by western blot with the pool of sera from each group and also with the pool of sera from specific pathogen free poultry used as negative control. The electrophoretic pattern showed the presence of many proteins of different serogroups of $E$. coli when grown in the broth casaminoacid and yeast. There were differences among serotypes, but also common proteins. It was possible to establish a relationship between virulence and reisolation rate.
\end{abstract}

Key words: Proteins. Escherichia coli. Western blot. Unidimensional electrophoresis. 


\section{LISTA DE FIGURAS}

Figura 1 - $\quad$ Esquematização dos tipos de Escherichia coli ............................................ 18

Figura 2 - Porcentagem de aves com algum grau de escore de lesão no período pósinoculação

Figura 3 - Porcentagem de aves com algum grau de escore de lesão aos 35 dias de idade

Figura 4 - Comparação do escore de lesão entre o período pós-inoculação (aves que morreram) e o dia do sacrifício (35 dias) quanto à porcentagem de escore de lesão

Figura 5 - Porcentagem de reisolamentos positivos para E. coli nos suabes dos órgãos das aves no dia do sacrifício (35 dias)

Figura 6 - Ave aos 24 dias de idade pertencente ao grupo 3 (EC 1695 - O2)

Figura 7 - Ave aos 35 dias de idade pertencente ao grupo 3 (EC 1695 - O2)

Figura 8 - Perfil eletroforético de proteínas obtidas de E. coli em gel de acrilamida $12 \%$ corado com Coomassie Blue (A) ou nitrato de prata (B)

Figura 9 - $\quad$ Reação de western blot em preparativo de proteínas do sorogrupo O2 (EC 1695) reagido com pool de soros dos diferentes grupos de aves infectadas experimentalmente e com soros de aves saudáveis

Figura 10 - Reação de western blot em preparativo de proteínas do sorogrupo O78 (EC 1696) reagido com pool de soros dos diferentes grupos de aves infectadas experimentalmente e com soros de aves saudáveis

Figura 11 - Reação de western blot em preparativo de proteínas do sorogrupo O119 (EC 341) reagido com pool de soros dos diferentes grupos de aves infectadas experimentalmente e com soros de aves saudáveis

Figura 12 - Reação de western blot em preparativo de proteínas do sorogrupo O78 de origem vacinal (EC 1934) reagido com pool de soros dos diferentes grupos de aves infectadas experimentalmente e com soros de aves saudáveis 


\section{LISTA DE TABELAS}

Tabela 1 - Número inicial de aves, mortalidade nos períodos pré-inoculação, pósinoculação e número de aves sacrificadas no fim do experimento

Tabela 2 - Frequência de aves necropsiadas e com algum grau de lesão (1 a 4) no período pós-inoculação ................................................................................ 36

Tabela 3 - Porcentagem de aves necropsiadas com algum grau de escore de lesão no período pós-inoculação quando avaliado os sacos aéreos torácicos direito (TD) e esquerdo (TE) e abdominal (AB), pericárdio (PC) e serosa hepática $(\mathrm{PH})$

Tabela 4- Aves sacrificadas e com algum grau de escore de lesão no fim do experimento (35 dias)

Tabela 5 - Porcentagem de aves sacrificadas e com algum grau de escore de lesão no fim do experimento (35 dias)

Tabela 6 - Quantidade de reisolamento positivo para E.coli nas aves dos grupos experimentais no dia do sacrifício (35 dias) 


\section{LISTA DE QUADROS}

Quadro 1 - Escores de lesão estabelecidos para o pericárdio, a serosa hepática e os sacos aéreos

Quadro 2 - Gel de separação a 12\% ........................................................................ 32

Quadro 3 - Gel de empilhamento a 5\% …............................................................. 32

Quadro 4 - Frequência de aves necropsiadas no período pós-inoculação e que tiveram escore de lesão variável de 0 a 4 em sacos aéreos torácico direito (TD), esquerdo (TE), abdominal (AB) e lesões sugestivas de pericardite (PC) e perihepatite $(\mathrm{PH})$

Quadro 5 - Aves sacrificadas aos 35 dias de idade e que tiveram escore de lesão variável de 0 a 4 em sacos aéreos torácico direito (TD), esquerdo (TE), abdominal $(\mathrm{AB})$ e lesões sugestivas de pericardite $(\mathrm{PC})$ e perihepatite $(\mathrm{PH}) \quad 38$ 


\section{SUMÁRIO}

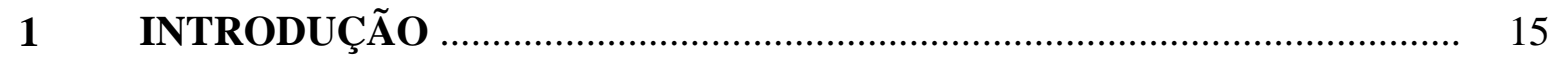

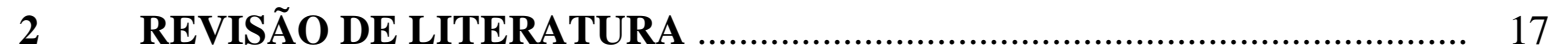

2.1 INTERAÇÃO BACTÉRIA E HOSPEDEIRO_................................................. 19

2.2 SECREÇÃO DE PROTEÍNAS POR BACTÉRIAS GRAM-NEGATIVAS ........ 21

2.3 VACINAS CONTRA A COLIBACILOSE AVIÁRIA ........................................ 23

2.4 DETECÇÃO DE ANTÍGENOS................................................................. 25

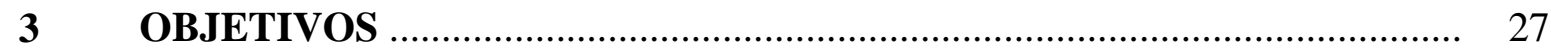

4 MATERIAL E MÉTODOS _................................................................. 28

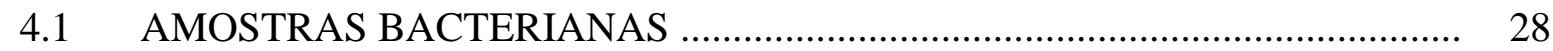

4.2 OBTENÇÃO DE PROTEÍNAS DE ESCHERICHIA COLI ............................... 28

4.3 INFECÇÃO EXPERIMENTAL …………………...................................... 29

4.3.1 Preparo das amostras para a inoculação …………………………………....... 31

4.4 ELETROFORESE UNIDIMENSIONAL EM GEL DE POLIACRILAMIDA SDS - PAGE ......................................................................................... 31

4.4.1 Coloração do gel de poliacrilamida ………………………….................. 32

4.5 REAÇÃO DE WESTERN BLOT ………………....................................... 33

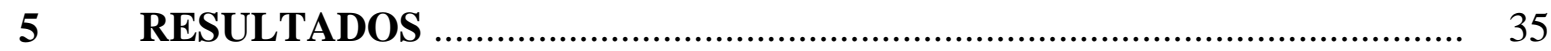

5.1 INFECÇÃO EXPERIMENTAL …………………………………………..... 35

5.2 ELETROFORESE EM GEL DE POLIACRILAMIDA ……………………....... 43

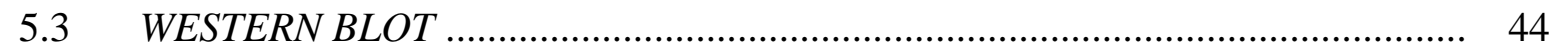

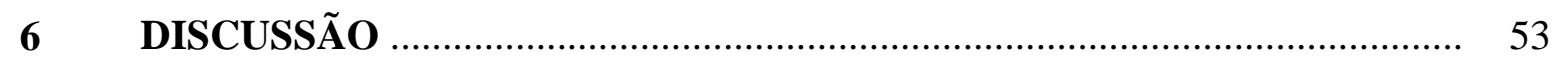

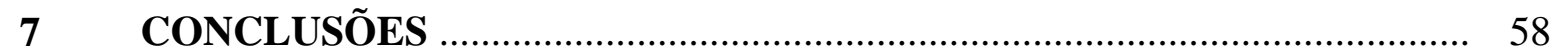

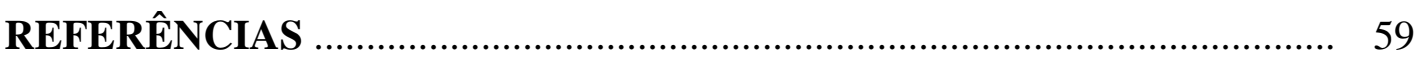




\section{INTRODUÇÃO}

As enfermidades causadas por Escherichia coli são de grande importância, visto que frequentemente ocorrem como agentes secundários e agravadores de doenças primárias. Nos EUA, a aerosaculite e a septicemia correspondem a $0,2 \%$ da taxa de condenação no abate de 170 milhões de aves processadas semanalmente. Esse índice pode ser agravado em épocas mais frias, devido a maior incidência de distúrbios respiratórios e imunossupressão. Calculase que o prejuízo com condenação de carcaças em consequência à septicemia, aerosaculite e processos infecciosos seja de aproximadamente $€ 38$ milhões anualmente nos EUA. Dentre as infecções bacterianas na avicultura, a colibacilose é a que causa maior mortalidade e morbidade, pois este agente possui grande capacidade de expressão de fatores de virulência e desenvolvimento de mecanismos de patogenicidade (SHANE, 2009).

As proteínas secretadas por bactérias Gram-negativas são importantes como antígenos para a produção de anticorpos específicos pelo hospedeiro durante a infecção. Dessa forma, antígenos com comprovada importância no curso da infecção podem ser usados na produção de uma proteína recombinante capaz de induzir a imunidade do hospedeiro.

O estudo das proteínas produzidas por um organismo é denominado proteômica, tratase de uma ciência variável, diferente da genômica que é estável, visto que proteínas bacterianas são produzidas de acordo com o ambiente e as condições a que são submetidas. Os métodos laboratoriais para a detecção de proteínas consistem em separação por peso molecular (eletroforese unidimensional) ou também por ponto isoelétrico (eletroforese bidimensional), após isto as proteínas podem ser submetidas a testes para a identificação de antígenos como no método western blot ou no desenvolvimento de ELISA.

A proteômica pode ser uma ferramenta de estudo dos mecanismos de resistência de certas bactérias e também para o controle da eficácia dos antimicrobianos utilizados (RADHOUANI et al., 2012). Além de pesquisa de formas de invasão e de como a enfermidade se desenvolve no hospedeiro, permite a avaliação e desenvolvimento de drogas e vacinas. Esta muito importante, tendo em vista que $E$. coli vem se tornando mais resistente a antibióticos, devido ao uso indiscriminado. Assim como, pela pressão do mercado cuja tendência é a redução do uso de antimicrobianos (CHANSIRIPORNCHAI, 2009).

Foram estudadas proteínas de E. coli quando cultivadas no meio de cultura casaminoácido e levedura para se verificar a presença de proteínas que poderiam ser 
relevantes no desenvolvimento da resposta imunológica de aves com colibacilose ou vacinadas com Poulvac ${ }^{\circledR}$ E.coli $\left(\right.$ Pfizer $\left.^{\circledR}\right)$. 


\section{REVISÃO DE LITERATURA}

Escherichia coli pertence à família Enterobacteriaceae, é um bastonete curto com coloração Gram-negativa, não esporulada, cujo tamanho varia de 1,1 a 1,5 $\mu$ m de largura, por 2 a $6 \mu \mathrm{m}$ de comprimento, anaeróbio facultativo, oxidase negativa, fermentador de açúcar e a maioria é móvel. Em meio sólido podem ser classificadas em: a) lisas quando são convexas, brilhantes e com bordos regulares, ou b) rugosas quando apresentam aparência grosseira e de contorno irregular (FERREIRA; KNOBL, 2009).

Em 1947, Kauffman sugeriu que as linhagens de E. coli fossem classificadas de acordo com os antígenos de superfície, sendo estes: antígenos somáticos $(\mathrm{O})$, capsulares $(\mathrm{K})$, flagelares $(\mathrm{H})$ e fimbriais (F). Existem cerca de 177 antígenos somáticos, 100 capsulares e 52 flagelares (FERREIRA; KNOBL, 2009). Os principais sorotipos relacionados com a colibacilose aviária são: O1:K1, O2:K1, O36 e O78:K80 (DHO-MOULIN et al., 1990). No Brasil, os sorogrupos prevalentes são: O2, O21, O36, O50, O78, O88, O119 e O152 (FERREIRA; KNOBL, 2009), embora outro estudo tenha demonstrado que algumas E. coli não tipáveis, possuam importância em quadros de onfalite (SILVEIRA et al., 2002).

Escherichia coli faz parte da microbiota entérica de aves e mamíferos e é adquirida após o nascimento, sendo que 10 a $20 \%$ destas podem apresentar potencial patogênico. Estudo realizado por Ewers et al. (2009) demonstrou que alguns fatores de virulência diferenciavam E. coli de origem aviária patogênicas das comensais. Apenas as primeiras apresentavam genes codificadores de fímbrias, transportadores de ferro e mecanismo de resistência ao sistema complemento do soro. No entanto, esses genes não eram exclusividade de E. coli patogênica, pois perfis de virulência semelhantes também foram encontrados em E. coli de origem fecal ou ambiental, sendo que algumas quando inoculadas em frangos saudáveis eram capazes de causar a doença, com sinais patológicos característicos de APEC. Diante disso, concluiu-se que $E$. coli de origem fecal ou ambiental poderia ser um reservatório significativo para a troca de genes importantes de virulência em E. coli de origem humana ou animal.

Escherichia coli quando classificada como patogênica, pode ser subdividida em dois grupos: a) E. coli patogênicas intestinais (Intestinal Pathogenic E.coli - IPEC) e b) E. coli patogênicas extra-intestinais (Extraintestinal Pathogenic E.coli - ExPEC). Entre as ExPEC estão: E. coli uropatogênica (Uropathogenic E.coli-UPEC), E. coli associada a meningite do recém nascido (Newborn Meningitic E.coli - NMEC), E. coli associada à septicemia 
(Septicaemia Associated E.coli - SePEC) e E. coli patogênica das aves (Avian Pathogenic E.coli - APEC), como demonstrado na figura 1, baseada em Antão (2010).

Figura 1 - Esquematização dos tipos de Escherichia coli

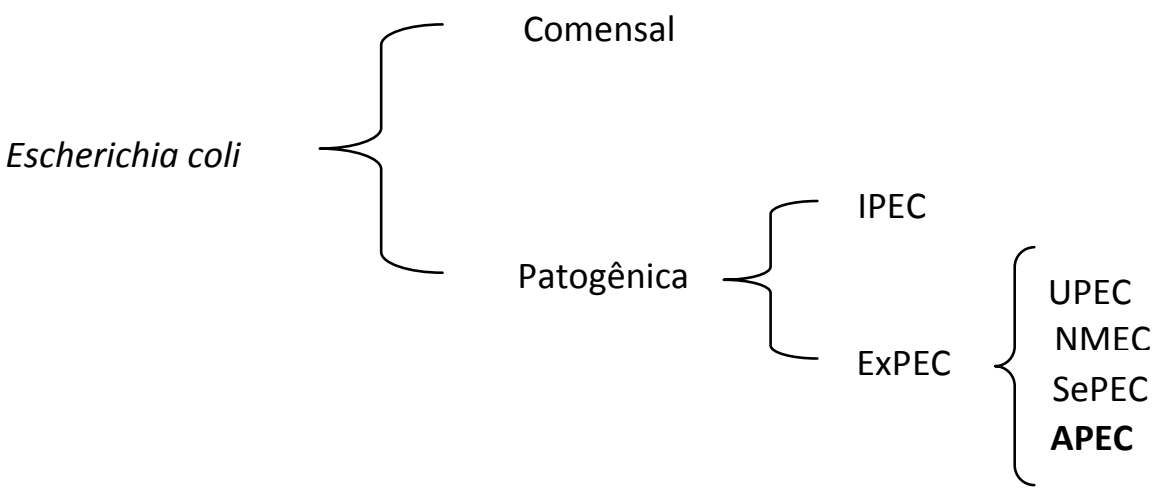

Fonte: Baseado em Antão (2010)

Os danos causados pela colibacilose possuem grande importância econômica em todas as fases da avicultura, pois atingem reprodutoras, poedeiras e frangos de corte. Nas reprodutoras as lesões mais frequentes são septicemia, peritonite e salpingite e nos frangos de corte ocorre septicemia e aerossaculite elevando a mortalidade e danificando a carcaça (SHANE, 2009).

Geralmente a colibacilose é secundária a uma infecção, e principalmente, associada a agentes como: Mycoplasma gallisepticum, Mycoplasma synoviae, Pasteurella multocida, Avibacterium paragallinarum, Pneumovírus, vírus da Bronquite infecciosa das galinhas, Marek, Newcastle e Gumboro (FERREIRA; KNOBL, 2009). Pode resultar em mortalidade superior a $20 \%$, inclusive em aves de vida longa como reprodutoras e poedeiras, pode causar danos à carcaça devido às alterações patológicas como colisepticemia, peritonite, pneumonia, pleuropneumonia, aerossaculite, pericardite, celulite, coligranuloma, doença respiratória crônica complicada, onfalite, salpingite, síndrome da cabeça inchada, panoftalmia, osteomielite, ooforite e sinovite (DHO-MOULIN; FAIRBROTHER, 1999).

Em aves, a infecção por $E$. coli pode ter início pela inalação de fezes contaminadas, desta forma a aderência ao trato respiratório (pulmões e sacos aéreos) ocorre através de fímbrias do tipo I. Em seguida, a bactéria pode atingir a corrente sanguínea, o que permite a adesão a outros órgãos como fígado e coração através da fímbria Curli, pois esta é capaz de unir-se a matriz extracelular, proteínas séricas e células intestinais, contribuindo para a septicemia. Os mecanismos de defesa do organismo hospedeiro são inicialmente a infiltração de heterófilos e posterior predominância de macrófagos (ANTÃO, 2010), todavia E. coli é 
capaz de resistir a estas células, pois quando sofrem fagocitose, ainda assim sobrevivem por até 48 horas. Após uma hora de infecção é possível verificar a ligação de $E$. coli às células do hospedeiro. A invasão da célula se dá em cerca de quatro horas, sendo variável entre os diferentes sorotipos (MATTER et al., 2010). A presença de vários fatores de virulência favorece a patogenicidade de Escherichia coli como: certos grupamentos O, antígenos capsulares K1 e K80, a resistência a antibióticos, presença de plasmídeos de alto peso molecular, a produção de colicinas (principalmente ColV), a presença de sideróforos (aerobactina), fímbrias, adesinas não fimbriais, motilidade, proteínas da membrana externa (OMPs), endotoxinas, resistência à fagocitose, hemaglutininas, enterotoxinas, toxinas citopáticas, hemolisinas, invasão de células e tecidos, persistência na corrente sanguínea ou tecidos (BARNES; NOLAN; VAILLANCOURT, 2008).

\subsection{INTERAÇÃO BACTÉRIA E HOSPEDEIRO}

As bactérias patogênicas, como alguns sorogrupos de E. coli, podem interagir com as células do hospedeiro através de proteínas de aderência ou pela liberação de exotoxinas. A aderência pode ocorrer pela fímbria curli, adesinas afimbriais ou fimbriais como o pili do tipo I. As subunidades encontradas na extremidade do pilus determinam a migração e interação com os órgãos do hospedeiro, no caso da fímbria curli a adesão se dá preferencialmente aos componentes da matriz extracelular, tais como fibronectina, laminina ou proteínas séricas (FINLAY; FALKOW, 1997).

A ativação do sistema imunológico depende da interação entre a bactéria e as células envolvidas na resposta imunológica do hospedeiro. Dessa forma, quando a bactéria consegue invadir as células do hospedeiro e se multiplicar, poderá liberar LPS e mucopeptídeos que ativarão os mecanismos de defesa como a fagocitose, a síntese de interleucina 6, a síntese de imunoglobulinas. Outro mecanismo de defesa do hospedeiro é a de sequestrar o íon ferro em lactoferrina ou transferrina, visto que todas as bactérias necessitam deste elemento para sobreviver. Assim, a infecção dependerá da capacidade de virulência bacteriana, se a bactéria possuir fatores que favoreçam o escape da resposta imunológica, a infecção será persistente.

Um dos mecanismos de escape bacteriano é a capacidade de resistir no interior do vacúolo fagocítico. Este fenômeno pode ocorrer através da modificação dos produtos 
bactericidas produzidos pela célula ou pela produção de novos compostos para prolongar a sobrevivência bacteriana no vacúolo. A bactéria também possui estruturas importantes para sobreviver como o LPS, o envelope celular, a produção de enzimas proteolíticas que destroem enzimas lisossomais, a capacidade de inibir a ligação do sistema complemento à bactéria tal como a proteína ISS (increased serum survival). Para obter o íon ferro do hospedeiro, a bactéria libera moléculas como o sideróforo e mesmo quando a disponibilidade é baixa, a bactéria é capaz de ativar outros mecanismos de virulência como toxinas, adesinas e invasinas. Esses mecanismos utilizados pela bactéria para prolongar a permanência no hospedeiro são denominados fatores de virulência e a maioria deles são proteínas secretadas ou presentes na superfície bacteriana. A regulação destes mecanismos de virulência é dependente de temperatura, concentração iônica, concentração do íon ferro, osmolaridade, $\mathrm{pH}$, disponibilidade de carbono, fase de crescimento da bactéria e disponibilidade de oxigênio. Os fatores de virulência são ativados de acordo com os sinais enviados pelas células do hospedeiro, como uma resposta ao meio ambiente em que a bactéria se encontra. Assim, os fatores de virulência são regulados por um sistema de dois componentes, onde a detecção de desequilíbrio no ambiente do hospedeiro, tais como a baixa quantidade de fosfato e carbono induz a síntese de fatores de virulência ativados (FINLAY; FALKOW, 1997).

Após o processo de colonização, a bactéria necessita atingir uma densidade populacional a fim de se estabelecer no hospedeiro ou ser transmitida para outro. Para isso há mecanismos de detecção da população bacteriana e também formas de auto-regulação da produção de fatores de virulência, tal processo é denominado quorum sensing. Os genes que codificam os fatores de virulência podem se situar lado a lado no cromossomo formando ilhas de patogenicidade, que podem conter genes para toxinas, sistemas de captação de ferro e sistemas de secreção tipo III. Os genes de virulência podem ser transmitidos entre bactérias, visto que podem estar em plasmídeos e outros elementos genéticos móveis (HACKER; KAPER, 2000).

Para compreender a invasão ao hospedeiro e como conseguem sobreviver nele, é preciso identificar os produtos gênicos que são necessários no processo de infecção. A expressão da maioria dos fatores de virulência é dependente do ambiente, mesmo quando in vitro, por isso é necessário a escolha de um meio de cultura que represente o animal in vivo (MAHAN; SLAUCH; MEKALANOS, 1993). 


\subsection{SECREÇÃO DE PROTEÍNAS POR BACTÉRIAS GRAM-NEGATIVAS}

A parede das bactérias Gram-negativas é composta por membrana interna, espaço periplasmático e membrana externa. Deste modo, a secreção proteica é um processo complexo devido à espessa parede celular, também porque a proteína é composta por regiões hidrofóbicas e hidrofílicas e deve passar por uma membrana lipídica e hidrofóbica (ECONOMOU, 1999). Além disso, várias proteínas devem se dobrar ou formar pontes bissulfídicas no periplasma antes de serem secretadas através da membrana externa (THANASSI; HULTGREN, 2000). As proteínas exportadas do citoplasma podem ser destinadas a: a) inserção na membrana interna, b) translocação através da membrana interna para o periplasma, c) inserção na membrana externa ou d) translocação através da membrana externa para o meio, sendo este considerado secreção, visto que é o processo no qual a proteína cruza a membrana externa (THANASSI; HULTGREN, 2000).

Há vários mecanismos de secreção proteica em bactérias Gram-negativas podendo ou não, existir gasto energético. As vias mais comuns de secreção proteica são:

Sec translocase: É a principal via de transporte de proteínas através da membrana interna. É um sistema fundamental para a viabilidade celular e que também pode funcionar em associação com outros métodos de transporte proteico. Cerca de $20 \%$ do proteoma de E. coli é composto por proteínas de membrana interna e a maioria entra na membrana através da via Sec translocase. Nesta via, a proteína a ser secretada é sinalizada no citoplasma, em E. coli esta é feita com o chaperoneo SecB ou SRP (signal recognition peptide) ligados à sequência amino-terminal (DRIESSEN; NOUWEN, 2008). Em seguida, na membrana interna bacteriana há SecA e SecYEG com as subunidades reguladoras SecD e SecF, destas, SecA é fundamental para o processo, pois se liga a proteína a ser transportada e também se liga a ATP para que seja gerada energia para o transporte. SecD e SecF atuam como catalizadores do transporte. Após a proteína atravessar a membrana interna ela será destinada ao local de interesse, o que é dependente de uma sequência de 20 a 30 resíduos de aminoácidos na porção amino terminal ou a presença de algum peptídeo sinal (MOAT; FOSTER; SPECTOR, 2002).

Tat (Twin arginine translocase): É um mecanismo que realiza o transporte através da membrana interna, onde se encontram proteínas denominadas Tat A, B, C, E que formam 
um canal para o transporte de proteínas dobradas. Alguns fatores de virulência de E. coli são Tat dependentes (MOAT; FOSTER; SPECTOR, 2002).

$\checkmark$ Chaperoneo / via de Usher: é o transporte através da membrana externa, composto por um chaperoneo periplásmico que agrupa as subunidades proteicas em estado competente para a secreção e que se liga ao poro de Usher. Responsável, principalmente, pela secreção de fatores de aderência como o pili tipo I. Esta via é sec dependente, por isso primeiramente a proteína é transportada pela via Sec translocase através da membrana interna, a sequência amino terminal é segmentada no periplasma, onde a proteína se liga ao chaperoneo que possibilita a travessia pelo canal de Usher situado na membrana externa (THANASSI; HULTGREN, 2000).

$\checkmark$ Two partner secretion (TPS): método que forma um canal na membrana externa para a secreção de proteínas, principalmente associadas a fatores de virulência (MOAT; FOSTER; SPECTOR, 2002).

$\checkmark$ Tipo I ou ABC (ATP - binding cassette): É um sistema que realiza o transporte através da membrana interna e externa. Na membrana interna possui uma enzima ATPase para a geração de energia para o transporte através da membrana interna, então é formado um canal entre a membrana interna e externa para a passagem da proteína, sem a necessidade de intermediários no periplasma (MOAT; FOSTER; SPECTOR, 2002). Este sistema é usado por E. coli para a secreção de hemolisina (THANASSI; HULTGREN, 2000).

$\checkmark$ Tipo II: Sistema que realiza o transporte do periplasma para a membrana externa, por isso depende de outro sistema que faça o transporte do citoplasma para a membrana interna e o periplasma, como a via Sec translocase ou Tat. As proteínas são transportadas dobradas (conformação secundária ou terciária) através de uma estrutura semelhante a um pilus, que é capaz de distinguir entre proteínas residentes no periplasma e destinadas a transporte. Trata-se de um mecanismo com gasto de ATP. Em geral, as proteínas que utilizam este mecanismo são enzimas hidrolíticas, toxinas, proteases e fosfolipases (MOAT; FOSTER; SPECTOR, 2002).

$\checkmark$ Tipo III: Complexo de transporte formado por mais de vinte proteínas que assumem a conformação de corpo flagelar que abrange a membrana interna e externa. Este se conecta com um pilus que alcança diretamente a membrana plasmática da célula eucariótica (THANASSI; HULTGREN, 2000). Isto torna a bactéria capaz de injetar a proteína diretamente na célula eucariótica, por isso é um sistema muito eficaz para a virulência (STATHOPOULOS et al., 2008). Todavia gera grande gasto energético, por isso é utilizado apenas quando a bactéria consegue contato próximo com a célula eucariótica. 
$\checkmark$ Tipo IV: Sistema composto por um pilus e que é capaz de injetar proteínas diretamente na célula eucariótica. Usado pela bactéria para a transferência de DNA durante o processo de conjugação e em alguns casos para o transporte de fatores de virulência como a proteína Tsh (STATHOPOULOS et al., 2008).

$\checkmark$ Tipo V ou autotransportadora: Sistema de transporte através da membrana externa que permite a passagem de proteínas desdobradas que assim permanecem por possuírem uma sequência amino terminal com 25 a 30 resíduos de aminoácidos. Primeiramente, o transporte é realizado através do citoplasma até a membrana interna o que ocorre comumente pelo mecanismo Sec translocase, em seguida a porção carboxi terminal da proteína se insere na membrana externa e origina um canal que realiza o autotransporte. A proteína então é liberada pela bactéria e se dobra adquirindo conformação funcional. Este mecanismo é utilizado por proteínas com cerca de 100KDa e a maioria delas está associada a fatores de patogenicidade, tal como a proteína Tsh (temperature sensitive hemagglutinin) (STATHOPOULOS et al., 2008), fatores de aderência, proteólise, citotoxicidade e formação de biofilme (MOAT; FOSTER; SPECTOR, 2002).

$\checkmark$ Tipo VI: encontrado em E. coli enteroagregativa, as proteínas transportadas são pequenas (menores que $20 \mathrm{KDa}$ ) (STATHOPOULOS et al., 2008). Estudo de Pace (2011) demonstrou que este sistema foi importante na virulência de APEC isolada do fígado de uma ave com septicemia, pois se verificou que ao serem deletados genes importantes para a formação deste sistema de secreção, a bactéria reduzia a capacidade de adesão, visto que não houve expressão de fímbria do tipo I.

\subsection{VACINAS CONTRA A COLIBACILOSE AVIÁRIA}

A colibacilose aviária é uma enfermidade relativamente frequente capaz de agravar outras pré-existentes e de relevância econômica, por isso tornam-se importantes medidas profiláticas o manejo de ventilação, temperatura, prevenção de enfermidades primárias através da vacinação e nutrição adequada das aves.

Por muito tempo os antimicrobianos foram as únicas ferramentas disponíveis para o tratamento da colibacilose, todavia as exigências de mercado têm restringido o uso dos mesmos, por isso a busca por vacinas eficazes para complementar a prevenção, o que é 
difícil, pois frequentemente há falhas quando se trata de imunização para diferentes sorotipos (LYNNE et al., 2012).

As vacinas disponíveis atualmente contra a colibacilose são: a) Coli-ave oleosa (Biovet $^{\circledR}$ ), uma vacina inativada composta por antígenos somáticos, pili e LPS dos sorogrupos O1, O2, O35 e O78 para o uso em reprodutoras e poedeiras; b) Nobilis E. coli Inac $\left(\right.$ Intervet $^{\circledR}$ ), indisponível no Brasil e composta por antígenos fimbriais F11 e FT para matrizes de frango de corte; c) Poulvac ${ }^{\circledR}$ E. coli $\left(\right.$ Pfizer $^{\circledR}$ ) uma vacina viva composta por E. coli O78:K80 com atenuação do gene Aro A.

Na vacina Poulvac ${ }^{\circledR}$ E.coli $\left(\right.$ Pfizer $^{\circledR}$ ) a atenuação do gene Aro A é importante para a sobrevivência bacteriana, visto que o mesmo está envolvido na síntese da enzima 5enolpiruvil shikimate-3-fosfato sintetase (EPSPS; 5-enolpyruvyl shikimate-3-phosphate synthase), que faz parte do sexto passo da via shikimate. Tal via é exclusiva de microorganismos e plantas (NATARAJAN et al., 2007) e atua na síntese de aminoácidos aromáticos essenciais como fenilalanina, triptofano e tirosina (HERRMANN, 1995). Desta forma, há imunização sem permanência prolongada no hospedeiro, apenas oito dias, reduzindo o risco de transmissão horizontal, sem risco de reversão de virulência e seguro para aves e mamíferos. Foi demonstrado em estudos da Pfizer ${ }^{\circledR}$ que o uso da Poulvac ${ }^{\circledR}$ E.coli em associação a outras vacinas como Newcastle, não interferia na imunização em relação à última e que a vacina conferia proteção tanto contra o sorotipo $\mathrm{O} 78$ como outros. A aplicação é por via spray e em frangos de corte uma dose é suficiente para a proteção até a idade de abate e pode ser usada em pintinhos de um dia de idade. Nos EUA e México a vacinação apresentou bons resultados de atenuação de sinais clínicos, redução de taxas de mortalidade e lesões características. É utilizada em poedeiras, reprodutoras e frangos de corte. A comercialização do produto no Brasil foi iniciada em outubro de 2010 (Fonte: Assessoria de Imprensa Pfizer).

Estudo realizado por Pfaff-McDonough et al. (2000), demonstrou que existia uma diferença altamente significativa na detecção do gene iss nas amostras de E. coli isoladas de aves doentes em relação àquelas de aves aparentemente saudáveis. Estes resultados sugeriam que esta proteína poderia ser usada como vacina. Assim, Lynne et al. (2012) realizaram um experimento com grupos de aves com duas semanas de idade, que foram vacinadas por via intramuscular com a proteína ISS recombinante. Após duas semanas da vacinação essas aves foram divididas em grupos, cada um desafiado com um sorogrupo de E. coli (O1, O2 e O78) e após uma semana as aves foram sacrificadas. Observou-se que não havia lesões significativas características de colibacilose nos grupos desafiados, além de existir a presença de anticorpos 
específicos a ISS tanto no soro como na mucosa dos sacos aéreos, independente do sorogrupo usado no desafio, portanto esta proteína pode proteger a aves contra a colibacilose.

\subsection{DETECÇÃO DE ANTÍGENOS}

Escherichia coli é um dos procariotos mais estudados, pois foi muito utilizada como modelo para análises bioquímicas, biológicas e diversos estudos biotecnológicos. Desde o sequenciamento do genoma por Blattner et al. em 1997, iniciou-se os estudos da proteômica e metabolômica, por meio de técnicas como o DNA microarray, a eletroforese bidimensional, a espectrometria de massa, a cromatografia e a bioinformática (HAN; LEE, 2006).

Diferente da transcriptômica que estuda a expressão gênica, a proteômica estuda a quantidade de proteínas produzidas e a resposta destas aos diferentes genótipos e condições como temperatura, variação de $\mathrm{pH}$, estresse oxidativo e privação de nutrientes (HAN; LEE, 2006). A proteômica permite o estudo das alterações proteicas após a tradução, o que não é possível apenas com o estudo do RNA mensageiro. É uma ciência variável, visto que proteínas geradas por um micro-organismo são moldadas de acordo com o estado funcional da célula e às condições a que são submetidas. Além disso, as proteínas produzidas são distintas quando em condições de infecção e outros estímulos externos, por isso a proteômica é considerada como o estudo da expressão gênica ao nível funcional. Esta ciência foi usada durante anos para se verificar a produção de proteínas e a expressão gênica em bactérias, assim, se aplica na área de microbiologia para a compreensão de mecanismos de doenças, formas de patogenicidade e avaliação de resistência de drogas. Para a identificação de proteínas que estimulam a imunidade podem ser usados anticorpos monoclonais ou policlonais em reações de western blot. Para a caracterização destas, há métodos de sequenciamento parcial de aminoácidos, identificação de aminoácidos que compõem a proteína ou de acordo com o peso molecular. A identificação pode ser facilitada quando o micro-organismo foi completamente sequenciado, é também usada para a taxonomia e a epidemiologia de micro-organismos (CASH, 2001).

A expressão imunoproteômica foi usada pela primeira vez por Jungblut em 2001, e é definida como um grupo de proteínas capazes de induzir uma resposta imunológica. A união de técnicas de proteômica como a eletroforese em gel de poliacrilamida com a reação de western blot gerou informações dos componentes imunogênicos presentes em um micro- 
organismo. Embora muitos imunógenos possam ser identificados (AYALEW et al., 2010), isto não significa que todos sejam capazes de induzir uma resposta imune protetora, que deve ser avaliada adequadamente por meio de ensaios in vivo (YANG et al., 2011). É importante para a compreensão da patogênese e também para o desenvolvimento de métodos diagnósticos e de vacinas (HU et al., 2012).

Os anticorpos circulantes no plasma de animais enfermos funcionam como um "imprint" molecular dos antígenos relacionados com as doenças autoimunes, câncer ou infecções e podem ser úteis como marcadores que auxiliam no diagnóstico (KRAH; JUNGBLUT, 2004). Considerando as infecções bacterianas, para se encontrar um marcador molecular é preciso que haja uma forte relação entre o antígeno produzido e a manifestação da doença, isto é verificado através de análises como a eletroforese bidimensional ou as que se baseiam, por exemplo, em imobilização de antígenos. Os anticorpos além de auxiliarem no diagnóstico podem ser úteis no controle de eficácia e desenvolvimento de vacinas e drogas terapêuticas (TJALSMA; SCHAEPS; SWINKELS, 2008).

A maioria das proteínas conhecidas de $E$. coli encontram-se no ponto isoelétrico entre o pH de 4 e 7 e peso molecular de 10 a 100 KDa (HAN; LEE, 2006), de acordo com Radhouani et al. (2012), estima-se que E. coli possua aproximadamente 4285 proteínas em seu proteoma completo, com ponto isoelétrico entre 3,38 e 13 e massa molecular entre 1,59 e $248 \mathrm{KDa}$. Esse proteoma completo é dividido em: citosol (2885 proteínas conhecidas), membrana interna (670 proteínas conhecidas), membrana externa (87 proteínas conhecidas) e periplasma (138 proteínas conhecidas). 


\section{OBJETIVOS}

Os objetivos deste trabalho foram:

$\checkmark$ Verificar o efeito do meio de cultura casaminoácido-levedura na produção de proteínas por Escherichia coli de diferentes sorogrupos $(\mathrm{O} 2, \mathrm{O} 78, \mathrm{O} 119)$ e de origem vacinal (Poulvac ${ }^{\circledR}$ E.coli $\left(\right.$ Pfizer $\left.^{\circledR}\right)$ );

$\checkmark$ Realizar infecção experimental de pintinhos com três diferentes sorogrupos de E. coli ou com a vacina Poulvac ${ }^{\circledR}$ E.coli $\left(\right.$ Pfizer $\left.^{\circledR}\right)$;

Identificar através de reação de western blot, proteínas específicas da colibacilose. 


\section{MATERIAL E MÉTODOS}

Serão descritos os materiais e a metodologia utilizados neste trabalho.

\subsection{AMOSTRAS BACTERIANAS}

Para este trabalho foram selecionados sorogrupos de Escherichia coli da coleção de culturas do Laboratório de Ornitopatologia - FMVZ - USP provenientes de aves com doença respiratória crônica. As amostras foram escolhidas visando sorogrupos diferentes e com potenciais de patogenicidade distintos, por isso escolheu-se: O2 (EC1695), O78 (EC1696) e O119 (EC341).

A bactéria vacinal presente em Poulvac ${ }^{\circledR}$ E.coli $\left(\right.$ Pfizer $^{\circledR}$ ) foi isolada e denominada EC1934. As quatro amostras bacterianas foram cultivadas em meio de cultura casaminoácido e levedura cuja composição é a seguinte: $2 \%$ de casaminoácido; $0,871 \%$ de $\mathrm{K}_{2} \mathrm{HPO}_{4} ; 0,6 \%$ de extrato de levedura; $0,25 \%$ de $\mathrm{NaCl} ; 0,1 \%$ (v/v) de solução com traços de sais; $1,5 \%$ de ágar. A solução com traços de sais foi feita separadamente e composta por $5 \%$ de $\operatorname{MgSO}_{4}\left(7 \mathrm{H}_{2} \mathrm{O}\right)$; 0,5\% de $\mathrm{MnCl}_{2}\left(4 \mathrm{H}_{2} \mathrm{O}\right) ; 0,5 \%$ de $\mathrm{FeCl}_{2}$ (EMERY et al., 1992; SALVADORI et al., 2001).

O meio casaminoácido e levedura foi utilizado para a secreção de VERO toxinas por E. coli (FANTINATTI, 1991), toxinas termolábeis (EMERY et al., 1992), produção de hemolisinas (SIMI, 1999) e toxinas termoestáveis (FANTINATTI, 1991).

\subsection{OBTENÇÃO DE PROTEÍNAS DE ESCHERICHIA COLI}

Para a obtenção de proteínas produzidas pelos quatro sorotipos de E. coli selecionados, utilizou-se o método de Camargo et al. (1991) com adaptações. Primeiramente, a bactéria era semeada em caldo casaminoácido e levedura por 18 horas a $37^{\circ} \mathrm{C}$, posteriormente, este caldo era distribuído em bandejas com ágar casaminoácido e levedura e estas incubadas por 18 horas a $37^{\circ} \mathrm{C}$, então era feita a raspagem da superfície do ágar e a diluição desta massa bacteriana em tampão fosfato salino (PBS) 0,1M, pH7,4 juntamente com inibidores de 
protease (BOLLAG; ROZYCKI; EDELSTEIN, 1996), sendo que a cada $1 \mathrm{~mL}$ de PBS 0,1M, pH7,4 eram adicionados: $100 \mu \mathrm{L}$ de EDTA $(0,3 \mathrm{mg} / \mathrm{mL}), 100 \mu \mathrm{L}$ de PMSF $(35 \mu \mathrm{g} / \mathrm{mL}), 10 \mu \mathrm{L}$ de pepstatina $(0,7 \mu \mathrm{g} / \mathrm{mL}), 10 \mu \mathrm{L}$ de aprotinina $(0,7 \mu \mathrm{g} / \mathrm{mL})$. A massa bacteriana diluída era colocada em tubos de ensaio com tampa $\left(\right.$ Falcon $\left.^{\circledR}\right)$ e homogeneizada no agitador. Em seguida, era centrifugada a $9000 \mathrm{x}$ g por 30 minutos a $4^{\circ} \mathrm{C}$. O sobrenadante era transferido para outro tubo de ensaio com tampa $\left(\right.$ Falcon $\left.^{\circledR}\right)$ e novamente centrifugado nas mesmas condições. O sobrenadante era retirado e filtrado com filtro de $0,20 \mu \mathrm{m}$, separado em alíquotas e estocado a $-80^{\circ} \mathrm{C}$ para posterior liofilização. Ao término do processo de filtragem, uma amostra era cultivada em BHI caldo por 18 horas a $37^{\circ} \mathrm{C}$ para a confirmação de esterilidade.

As proteínas foram quantificadas através da reação com ácido bicinconínico utilizando Micro BCA kit (Pierce $\left.^{\circledR}\right)$ de acordo com as instruções do fabricante.

As amostras liofilizadas foram dialisadas em membrana Snake Skin (Pierce ${ }^{\circledR}$ ) de 10.000 MWCO (molecular weight cut-off, unidade em Daltons) por 24 horas a $4^{\circ} \mathrm{C}$ com várias trocas de PBS 0,1M, pH7,4 e então divididas em alíquotas e estocadas a $-80^{\circ} \mathrm{C}$.

\subsection{INFECÇÃO EXPERIMENTAL}

O alojamento das aves foi feito em galpão, em boxes de $1,7 \mathrm{~m}^{2}$, localizado no aviário da FMVZ-USP. Os pintinhos eram matrizes machos, da linhagem Ross (Aviagen ${ }^{\circledR}$ ). No primeiro dia de criação foram divididos aleatoriamente em três grupos de 20 aves cada (grupos 2, 3 e 4) e um grupo de 25 aves (grupo 1), totalizando 85 pintinhos. Os grupos foram denominados:

$\checkmark$ GRUPO 1: Grupo inoculado por via saco aéreo torácico, com $1 \times 10^{6}$ UFC.mL $^{-1}$ do sorogrupo O119 de Escherichia coli (EC341), aos 14 dias de idade.

$\checkmark$ GRUPO 2: Grupo vacinado com Poulvac ${ }^{\circledR}$ E.coli (Pfizer ${ }^{\circledR}$ ) por via ocular, aos 14 dias de idade (EC 1934, sorogrupo O78).

$\checkmark$ GRUPO 3: Grupo inoculado por via saco aéreo torácico, com $1 \times 10^{6}$ UFC.mL $^{-1}$ do sorogrupo O2 de Escherichia coli (EC1695), aos 14 dias de idade.

$\checkmark$ GRUPO 4: Grupo inoculado por via saco aéreo torácico, com $1 \times 10^{6}$ UFC.mL $^{-1}$ do sorogrupo O78 de Escherichia coli (EC1696), aos 14 dias de idade.

Durante todo o período de criação a mortalidade era anotada e realizada a necropsia. A ração e água eram fornecidos à vontade e os bebedouros higienizados diariamente. 
O cronograma de atividades realizadas:

$\checkmark 1$ dia de idade: Alojamento das aves e divisão aleatória em quatro boxes de $1,7 \mathrm{~m}^{2}$.

14 dias de idade: Desafio das aves dos grupos 1, 3 e 4 pela inoculação por via saco aéreo torácico esquerdo e vacinação por via ocular das aves do grupo 2 com Poulvac ${ }^{\circledR}$ E.coli $\left(\right.$ Pfizer $\left.^{\circledR}\right)$. Todas as aves que vieram a óbito foram necropsiadas e avaliadas qualitativamente quanto ao grau de lesão sugestivo de colibacilose. O escore de lesão variou de zero (ausência) a quatro (grau mais intenso) para a presença de aerossaculite, pericardite e perihepatite, baseado em Goren (1978) com algumas modificações, como demonstrado no quadro 1.

35 dias de idade: Colheita de sangue de todas as aves pela veia ulnar, seguido de sacrifício em câmera de $\mathrm{CO}_{2}$, necropsia para a qualificação das lesões sugestivas de colibacilose e suabe dos órgãos para o reisolamento de E. coli. As aves foram identificadas, por isso era possível saber a correspondência entre lesões macroscópicas e sangue colhido. Após a colheita do sangue das aves, o soro foi separado e estocado a $-20^{\circ} \mathrm{C}$.

Quadro 1 - Escores de lesão estabelecidos para o pericárdio, a serosa hepática e os sacos aéreos

\begin{tabular}{|l|c|}
\hline \multicolumn{1}{|c|}{ Local e descrição } & Escore \\
\hline Pericárdio & \\
Normal & 0 \\
Quantidade excessiva de fluido claro dentro do saco pericárdico & 1 \\
Fluido turvo dentro do saco pericárdico e/ou opacidade no pericárdio & 2 \\
Presença de algumas placas de fibrina no pericárdio & 3 \\
Placas extensas de fibrina que revestem todo o pericárdio & 4 \\
\hline Serosa hepática & \\
Normal & 0 \\
Presença de fibrina em baixa quantidade & 1 \\
Placas de fibrina na superfície hepática & 2 \\
Placas de fibrina extensas e que formam aderência no tecido hepático & 3 \\
Placas extensas e espessas de fibrina que revestem todo o fígado & 4 \\
\hline Sacos aéreos: torácicos direito e esquerdo e abdominal & \\
Leve opal & 0 \\
Opacidade localizada dos sacos aéreos e com presença de exsudato & 2 \\
Opacidade extensa com grande quantidade de exsudato & 3 \\
Opacidade extensa e presença de placas de fibrina & 4 \\
\hline
\end{tabular}

Fonte: Baseado em Goren (1978). 


\subsubsection{Preparo das amostras para a inoculação}

O inóculo foi preparado individualmente. Cada cepa bacteriana foi semeada em ágar McConkey, as colônias foram mensuradas e colocadas em BHI caldo em agitação de 200rpm a $37^{\circ} \mathrm{C}$, sendo que periodicamente era coletada uma alíquota para se verificar a densidade ótica em comprimento de onda de 420nm. Baseado em ensaios prévios foi estabelecida a densidade ótica necessária para que cada cepa bacteriana tivesse uma concentração de aproximadamente, $1 \times 10^{6}$ UFC.mL ${ }^{-1}$. Desta forma, a cultura bacteriana foi inoculada na quantidade de $0,1 \mathrm{~mL} /$ ave, por via saco aéreo torácico esquerdo.

A vacina utilizada no grupo 2 foi Poulvac ${ }^{\circledR}$ E.coli (Pfizer ${ }^{\circledR}$ ) (Partida: 001/10; Fabr.: Jul/10; venc.: Jul/12) preparada com diluente de vacina. Um frasco suficiente para 2500 doses foi diluído em $75 \mathrm{~mL}$ de diluente de vacina Pro ocular (Pfizer ${ }^{\circledR}$ ), conforme instruções do fabricante e instilado uma gota por ave.

4.4 ELETROFORESE UNIDIMENSIONAL EM GEL DE POLIACRILAMIDA - SDSPAGE

A separação das proteínas por peso molecular foi realizada através de eletroforese unidimensional em gel de poliacrilamida com desnaturação das proteínas com dodecil sulfato de sódio (SDS) e uso de gel descontínuo baseado em Laemmli (1970). Todo o protocolo foi seguido de acordo com Garfin (2009).

As amostras foram preparadas com tampão de amostra (50,5\% de água ultra pura; 12,6\% de Tris-Cl 0,5M, pH6,8; 4,4\% de SDS 10\%; 10,5\% de glicerol; 5\% de azul de bromofenol $0,5 \% ; 5 \%$ de 2 - mercaptoetanol) e fervidas por cinco minutos, em seguida adicionadas ao gel de acrilamida descontínuo composto por gel de empilhamento a $5 \%$ e de separação a $12 \%$ (quadros 2 e 3 ).

A eletroforese foi feita na forma de preparativo e a quantidade de proteína a ser colocada foi definida de modo a se obter a melhor resolução na reação de western blot. A eletroforese foi realizada a $100 \mathrm{~V}$ no gel de empilhamento e $200 \mathrm{~V}$ no gel de separação. Inicialmente, se testou uma concentração padrão para todos os sorotipos, todavia isto não foi possível, visto que a concentração proteica obtida da vacina era muito baixa e não era possível 
se fazer uma comparação com os demais sorotipos na reação de western blot. Como as proteínas dos diferentes sorotipos apresentaram quantidade de bandas e concentração entre bandas de forma variável, optou-se por variar a concentração das proteínas, para permitir uma melhor avaliação na reação de western blot. Desta forma, as proteínas obtidas foram

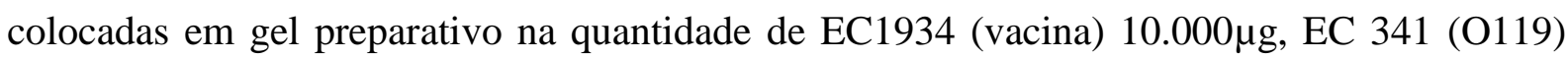

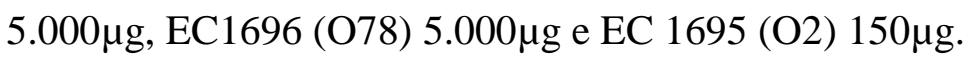

Como peso molecular foi usado o Prestained Molecular Weight Marker (Sigma Aldrich $^{\circledR}$ ), sendo que as proteínas padrão possuíam os pesos moleculares de $180 \mathrm{KDa}$ (subunidade de alfa macroglobulina de soro equino), $116 \mathrm{KDa}$ (beta-galactosidase de E. coli), $90 \mathrm{KDa}$ (lactoferrina de leite humano), $58 \mathrm{KDa}$ (piruvato quinase de músculo de coelho), 48,5 $\mathrm{KDa}$ (fumarase de coração suíno), 36,5 KDa (desidrogenase láctica de músculo de coelho) e 26,6 KDa (triofosfato isomerase de músculo de coelho).

Quadro 2 - Gel de separação a $12 \%$

\begin{tabular}{ll}
\hline Água ultra pura & $6,7 \mathrm{~mL}$ \\
Tampão de separação & $5,0 \mathrm{~mL}$ \\
SDS 10\% & $200 \mu \mathrm{L}$ \\
Acrilamida 30\% : bis-acrilamida $0,8 \%$ & $8,0 \mathrm{~mL}$ \\
Persulfato de amônio 10\% & $120 \mu \mathrm{L}$ \\
TEMED & $20 \mu \mathrm{L}$ \\
\hline VOLUME FINAL & $20,04 \mathrm{~mL}$ \\
\hline Fonte: Baseado em Garfin (2009) & \\
& \\
Quadro 3 - Gel de empilhamento a 5\% & \\
\hline Água ultra pura & $6,1 \mathrm{~mL}$ \\
Tampão de empilhamento & $2,5 \mathrm{~mL}$ \\
Acrilamida 30\% : bis-acrilamida $0,8 \%$ & $1,3 \mathrm{~mL}$ \\
SDS 10\% & $100 \mu \mathrm{L}$ \\
Persulfato de amônio 10\% & $50 \mu \mathrm{L}$ \\
TEMED & $20 \mu \mathrm{L}$ \\
\hline VOLUME FINAL & $10,07 \mathrm{~mL}$ \\
\hline
\end{tabular}

Fonte: Baseado em Garfin (2009)

\subsubsection{Coloração do gel de poliacrilamida}

Após a eletroforese, o gel foi corado com Coomassie blue 250R (Sigma Aldrich ${ }^{\circledR}$ ) ou nitrato de prata. No primeiro método o gel era fixado em solução contendo $40 \%$ de metanol, 
$10 \%$ de ácido acético e $50 \%$ de água ultra pura e corado com solução de Coomassie blue 0,25\%. Quando utilizado o método de coloração por nitrato de prata (BLUM; BEIER; GROSS, 1987), o gel era fixado em solução de 50\% de metanol, $12 \%$ de ácido acético, 0,5\% de solução de formaldeído $37 \%$ por pelo menos uma hora. Em seguida, era lavado com solução de etanol $50 \%$ por vinte minutos, por três vezes. O gel foi colocado em solução de pré-tratamento por um minuto $\left(\mathrm{Na}_{2} \mathrm{~S}_{2} \mathrm{O}_{3} .5 \mathrm{H}_{2} \mathrm{O} 0,02 \%\right)$, depois lavado com água ultra pura por três vezes, por vinte segundos e transferido para a solução de impregnação por vinte minutos $\left(\mathrm{AgNO}_{3}\right.$ 0,2\%, 0,075\% de solução de formaldeído 37\%). O gel era lavado em água ultra pura por vinte segundos, por três vezes e transferido para a solução reveladora $\left(\mathrm{Na}_{2} \mathrm{CO}_{3} 6 \%, 0,05 \%\right.$ de solução de formaldeído $37 \%, \mathrm{Na}_{2} \mathrm{~S}_{2} \mathrm{O}_{3} .5 \mathrm{H}_{2} \mathrm{O}$ 0,0004\%) até o aparecimento das bandas. $\mathrm{O}$ gel era lavado em água ultra pura por duas vezes de dois minutos cada e então colocado em solução de parada (50\% de metanol, $12 \%$ de ácido acético) por dez minutos e estocado em metanol $50 \%$ a $4^{\circ} \mathrm{C}$.

\subsection{REAÇÃO DE WESTERN BLOT}

O método de western blot utilizado foi baseado em Towbin, Stahehelin e Gordon (1979). Após a eletroforese, o gel foi incubado em tampão de transferência (Tris 48mM, Glicina 39mM, SDS 0,037\% e Metanol 20\%) por 30 minutos, sob agitação. A membrana de

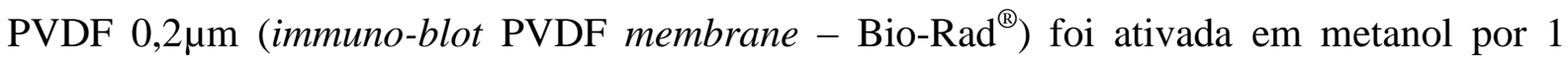
minuto, e em seguida submersa em tampão de transferência por 30 minutos, em agitação. $\mathrm{O}$ filtro de papel Whatman $3 \mathrm{~mm}$ foi umedecido em tampão de transferência, para a montagem do sanduíche na cuba de transferência, na ordem, um sobre o outro: duas folhas de papel filtro, membrana de PVDF $0,2 \mu \mathrm{m}$, o gel de acrilamida e três folhas de papel filtro. A transferência foi feita em fonte Bio-Rad 1.3 e cuba de transferência Trans-Blot SD Semi-Dry Electrophoretic Transfer cell (Bio-Rad $\left.{ }^{\circledR}\right)$ a 12 Volts por uma hora e vinte minutos. Após isso, a membrana foi incubada por duas horas em leite desnatado $5 \%$ em solução de PBS $0,1 \mathrm{M}, \mathrm{pH}$ 7,4. Em seguida, a membrana foi lavada com PBS-Tween 20 (PBS 0,1M, pH 7,4 e Tween 20 $0,02 \%$ ) por cinco minutos, por três vezes. O soro sanguíneo, denominado anticorpo primário, foi adicionado, este diluído em leite desnatado $1 \%$ em PBS $0,1 \mathrm{M}, \mathrm{pH} 7,4$ por uma hora na proporção de 1:400, 1:200 ou 1:100. Após este período foi feita a lavagem da membrana com solução de PBS-Tween 20 por cinco minutos, por três vezes. A membrana foi transferida para 
uma solução de leite desnatado $1 \%$ em PBS 0,1M, pH 7,4 com anticorpos de galinha conjugado com peroxidase, denominado anticorpo secundário (anti-IgG), na proporção de 1:3000 ou 1:2000 e incubado por uma hora, sob agitação. A membrana foi novamente lavada com PBS-Tween 20 por um minuto, por cinco vezes. O revelador da reação foi adicionado, sendo este preparado imediatamente antes do uso $(6 \mathrm{mg}$ de diaminobenzina tetrahidrocloreto (DAB), 9mL de Tris-HCl 0,01M, pH 7,6 e 1mL de cloreto de cobalto 0,1\%). Logo em seguida, $10 \mu \mathrm{l}$ de peróxido de hidrogênio $30 \%$, foi acrescentado à reação e a membrana foi mantida nesta solução até o aparecimento de bandas. A reação foi interrompida com água ultra pura, e a membrana conservada em papel filtro até a secagem (ASTOLFI-FERREIRA, 2001).

A reação de western blot foi realizada com uma mistura de soro das aves pertencentes ao mesmo grupo experimental e também com soros de aves de 35 dias de idade, livres de patógenos específicos $\left(S P F\right.$, gentilmente cedido pela Biovet $\left.{ }^{\circledR}\right)$. Todos os soros foram reagidos com as proteínas obtidas das quatro amostras de Escherichia coli estudadas (EC1695, EC1696, EC341 e EC1934). 


\section{RESULTADOS}

Os resultados obtidos neste experimento estão descritos nos itens a seguir.

\subsection{INFECÇÃO EXPERIMENTAL}

O experimento foi dividido em três etapas: pré-inoculação (1 a 13 dias), pósinoculação/vacinação (14 a 34 dias) e dia do sacrifício (35 dias).

Em todos os grupos, exceto no grupo 2 (EC 1934 - amostra vacinal), houve mortalidade no período pré-inoculação. No grupo 4 (EC 1696) a mortalidade foi superior a ocorrida no período pós-inoculação, todavia as mortalidades neste período $(\mathrm{n}=03)$ foram de aves refugo.

No período pós-inoculação, a maior taxa de mortalidade foi no grupo 1 (EC 341), no qual houve a morte de seis (06) aves.

Nos grupos 2 (EC 1934) e 4 (EC 1696) não houve mortalidade no período pósinoculação.

$\mathrm{Na}$ tabela 1 estão representados os grupos, número de aves no início do experimento para cada grupo, a mortalidade no período pré-inoculação, pósinoculação e o sacrifício das aves ao término do experimento.

Tabela 1 - Número inicial de aves, mortalidade nos períodos pré-inoculação, pós-inoculação e número de aves sacrificadas no fim do experimento

\begin{tabular}{lcccc}
\hline \multicolumn{1}{c}{ Grupo } & $\begin{array}{c}\text { Número } \\
\text { inicial }\end{array}$ & $\begin{array}{c}\text { Pré- } \\
\text { inoculação }\end{array}$ & $\begin{array}{c}\text { Pós- } \\
\text { inoculação }\end{array}$ & Sacrifício \\
\hline $\begin{array}{l}\text { 1 (inoculado com EC 341 - } \\
\text { O119) }\end{array}$ & 25 & 1 & 6 & 18 \\
2 (vacinado sorogrupo O78) & 20 & 0 & 0 & 20 \\
3 (inoculado com EC1695 - & 20 & 1 & 2 & 17 \\
O2) & 20 & 3 & 0 & 17 \\
$\begin{array}{l}\text { 4 (inoculado com EC 1696 - } \\
\text { O78) }\end{array}$ & & & & \\
\hline
\end{tabular}

No período pós-inoculação, as aves que vieram a óbito foram necropsiadas para a avaliação de escore de lesão. Houve mortalidade nos grupos 1 (EC 341) e 3 (EC 
1695), respectivamente, com seis (06) e duas (02) aves. Todas as aves necropsiadas do grupo 1 (EC 341) apresentaram lesões em sacos aéreos e pericárdio e apenas uma (01) ave não apresentou lesão em serosa hepática. Nos sacos aéreos torácicos as lesões variaram de grau 2 a 4, nos sacos aéreos abdominais três (03) aves apresentaram escore 1, uma (01) escore 3 e duas (02) escore 4, em relação à serosa hepática a maioria das aves apresentou lesão discreta com opacidade da serosa. No grupo 3 (EC 1695) as duas (02) aves apresentaram lesões em sacos aéreos torácicos, pericárdio e serosa hepática e apenas uma (01) apresentou lesão em saco aéreo abdominal. Uma das aves apresentou sinais discretos de colibacilose com ausência de lesões ou com escore 1, enquanto a outra ave possuía lesões intensas de grau 4 com espessamento de serosa hepática, deposição de fibrina no fígado e coração, como demonstrado na figura 6.

No quadro 4 se encontra a frequência dos escores de lesão das aves que vieram a óbito no período pós-inoculação. A tabela 2 mostra a frequência de aves com algum grau de lesão no período pós-inoculação, a tabela 3 apresenta a frequência em porcentagem e na figura 2 se encontra o gráfico referente a esta porcentagem.

Quadro 4 - Frequência de aves necropsiadas no período pós-inoculação e que tiveram escore de lesão variável de 0 a 4 em sacos aéreos torácicos direito (TD), esquerdo (TE), abdominal (AB) e lesões sugestivas de pericardite $(\mathrm{PC})$ e perihepatite $(\mathrm{PH})$

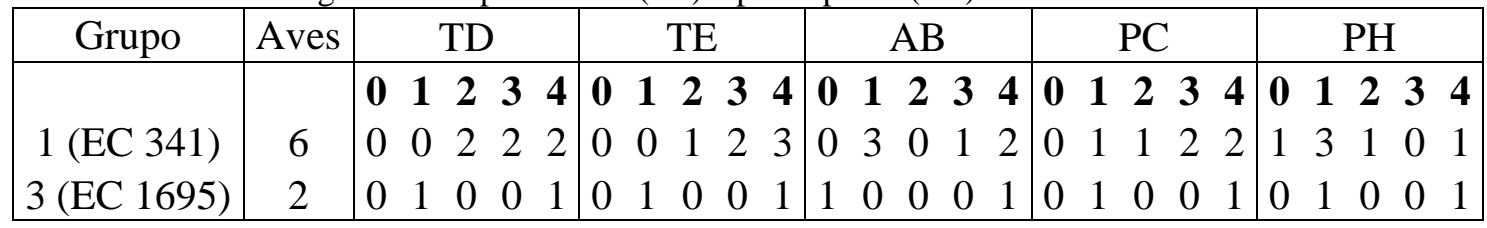

Tabela 2 - Frequência de aves necropsiadas e com algum grau de escore de lesão (1 a 4) no período pós-inoculação

\begin{tabular}{ccccccc}
\hline Grupo & Aves & T.direito & T.esquerdo & Abdominal & Pericardite & Perihepatite \\
\hline 1 (EC 341) & 6 & 6 & 6 & 6 & 6 & 5 \\
3 (EC 1695) & 2 & 2 & 2 & 1 & 2 & 2 \\
\hline
\end{tabular}

Tabela 3 - Porcentagem de aves necropsiadas com algum grau de escore de lesão no período pósinoculação quando avaliado sacos aéreos torácicos direito (TD) e esquerdo (TE) e abdominal $(\mathrm{AB})$, pericárdio $(\mathrm{PC})$ e serosa hepática $(\mathrm{PH})$

\begin{tabular}{cccccc}
\hline Grupo & TD $(\%)$ & TE $(\%)$ & AB $(\%)$ & PC $(\%)$ & PH (\%) \\
\hline 1 (EC 341) & 100 & 100 & 100 & 100 & 83,33 \\
$3($ EC 1695) & 100 & 100 & 50 & 100 & 100 \\
\hline
\end{tabular}


Figura 2 - Porcentagem de aves com algum grau de escore de lesão no período pós-inoculação

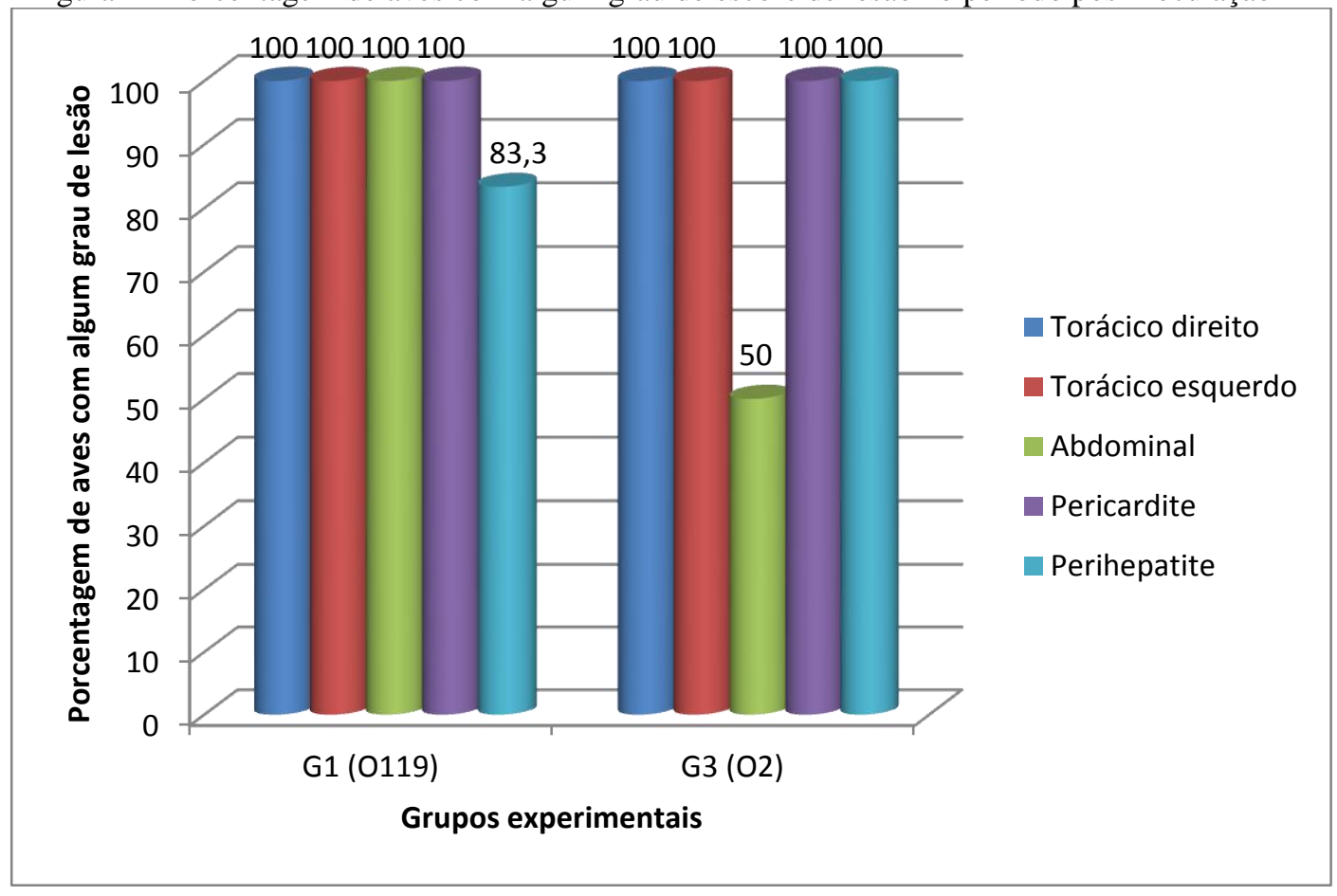

Aos 35 dias de idade (21 dias após o desafio com E. coli) as aves foram sacrificadas. As aves do grupo 2 (EC 1934 - amostra vacinal) não apresentaram lesões sugestivas de colibacilose, exceto uma ave que apresentou lesão moderada no pericárdio (grau 2).

Todas as aves do grupo 3 (EC 1695 - O2) apresentaram lesões nos sacos aéreos torácicos direito e esquerdo que variaram de escore 1 a 4 , enquanto as aves do grupo 4 (EC1696 - O78) não apresentaram lesões nos sacos aéreos abdominais, pericárdio ou serosa hepática, mas houve lesões de escore 1 e 2 nos sacos aéreos torácicos direito e esquerdo.

No quadro 5 se encontra o número de aves sacrificadas aos 35 dias de idade e a avaliação dos escores de lesão das mesmas. Nas tabelas 4 e 5 estão descritas a frequência e a porcentagem de aves com algum grau de lesão no mesmo período. No grupo 1 (EC 341 - O119), a maior incidência de lesão ocorreu nos sacos aéreos torácicos direito (89\%) e esquerdo (78\%), apenas duas (02) aves apresentaram lesões em sacos aéreos abdominais de escore 1 e oito (08) aves apresentavam sinais de pericardite com escore variável entre 1 e 3 , nenhuma ave apresentou lesão em serosa hepática. No grupo 2 (EC 1934 - amostra vacinal) nenhuma das vinte aves necropsiadas apresentaram lesões em sacos aéreos ou serosa hepática, apenas uma (01) 
ave possuía lesão de escore 2 em pericárdio. No grupo 3 (EC 1695 - O2) as dezessete aves necropsiadas apresentavam algum grau de lesão em sacos aéreos torácicos sendo a maioria com escore 1 ou 2, apenas duas (02) aves apresentaram lesão de escore $1 \mathrm{em}$ sacos aéreos abdominais, cinco (05) aves apresentaram lesão de escore 1 no pericárdio e duas (02) aves possuíam lesão em serosa hepática, sendo uma delas discreta (grau 1) e outra intensa (grau 4). No grupo 4 (EC 1696 - O78) as 17 aves necropsiadas não tiveram lesões em sacos aéreos abdominais, pericárdio ou serosa hepática, $18 \%$ e 29\% das aves apresentavam algum grau de lesão em sacos aéreos torácicos direito e esquerdo, respectivamente.

A figura 3 apresenta a porcentagem de aves com algum grau de lesão aos 35 dias de idade.

Quadro 5 - Aves sacrificadas aos 35 dias de idade e que tiveram escore de lesão variável de 0 a 4 em sacos aéreos torácicos direito (TD), esquerdo (TE), abdominal (AB), lesões sugestivas de pericardite $(\mathrm{PC})$ e perihepatite $(\mathrm{PH})$

\begin{tabular}{|c|c|c|c|c|c|c|c|c|c|c|c|c|c|c|c|c|c|c|c|c|c|c|}
\hline Grupo & $\mathrm{n}$ & \multicolumn{4}{|c|}{$\mathrm{TD}$} & & \multicolumn{5}{|c|}{ TE } & \multicolumn{4}{|c|}{$\mathrm{AB}$} & \multicolumn{4}{|c|}{$\mathrm{PC}$} & \multicolumn{3}{|c|}{$\mathrm{PH}$} \\
\hline & & 0 & 1 & 2 & & & 0 & 1 & 2 & 3 & & 0 & 12 & 23 & & & 12 & 23 & & $\mathbf{0}$ & 12 & 34 \\
\hline 1 & 18 & 2 & 11 & 4 & & 0 & 4 & 10 & 4 & 0 & & 16 & 2 & 0 & 0 & 10 & 42 & 22 & 0 & 18 & 00 & $\begin{array}{ll}0 & 0\end{array}$ \\
\hline 2 & 20 & 20 & 0 & 0 & 0 & 0 & 20 & 0 & 0 & 0 & & 20 & 00 & 0 & 0 & 19 & $\begin{array}{ll}0 & 1\end{array}$ & 10 & 0 & 20 & $\begin{array}{ll}0 & 0\end{array}$ & \\
\hline 3 & 17 & 0 & 9 & 6 & 1 & 1 & 0 & 8 & 3 & 5 & & 15 & 20 & 00 & 0 & 12 & 50 & $0 \quad 0$ & 0 & 15 & 10 & \\
\hline 4 & 17 & 14 & 2 & 1 & 0 & 0 & 12 & 4 & 1 & 0 & & 17 & $\begin{array}{ll}0 & 0\end{array}$ & 00 & 0 & 17 & $\begin{array}{ll}0 & 0 \\
\end{array}$ & 00 & 0 & 17 & $\begin{array}{ll}0 & 0 \\
\end{array}$ & $\begin{array}{ll}0 & 0 \\
\end{array}$ \\
\hline
\end{tabular}

Tabela 4 - Aves sacrificadas e com algum grau de escore de lesão no fim do experimento (35 dias)

\begin{tabular}{ccccccc}
\hline Grupo & Aves & T.direito & T.esquerdo & Abdominal & Pericardite & Perihepatite \\
\hline 1 (EC 341 - & 18 & 16 & 14 & 2 & 8 & 0 \\
O119) & & & & & & \\
2 (vacinado) & 20 & 0 & 0 & 0 & 1 & 0 \\
3 (EC 1695 - & 17 & 17 & 17 & 2 & 5 & 2 \\
O2) & & & 5 & 0 & 0 & 0 \\
4 (EC 1696- & 17 & 3 & 5 & & & \\
O78) & & & &
\end{tabular}

Tabela 5 - Porcentagem de aves sacrificadas e com algum grau de escore de lesão no fim do experimento (35 dias)

\begin{tabular}{cccccc}
\hline Grupo & $\mathrm{TD}(\%)$ & $\mathrm{TE}(\%)$ & $\mathrm{AB}(\%)$ & $\mathrm{PC}(\%)$ & $\mathrm{PH}(\%)$ \\
\hline 1 (EC 341- O119) & 89 & 78 & 11 & 44 & 0 \\
2 (vacinado) & 0 & 0 & 0 & 5 & 0 \\
3 (EC 1695 - O2) & 100 & 100 & 12 & 29 & 12 \\
4 (EC 1696- O78) & 18 & 29 & 0 & 0 & 0 \\
\hline
\end{tabular}


Figura 3 - Porcentagem de aves com algum grau de escore de lesão aos 35 dias de idade

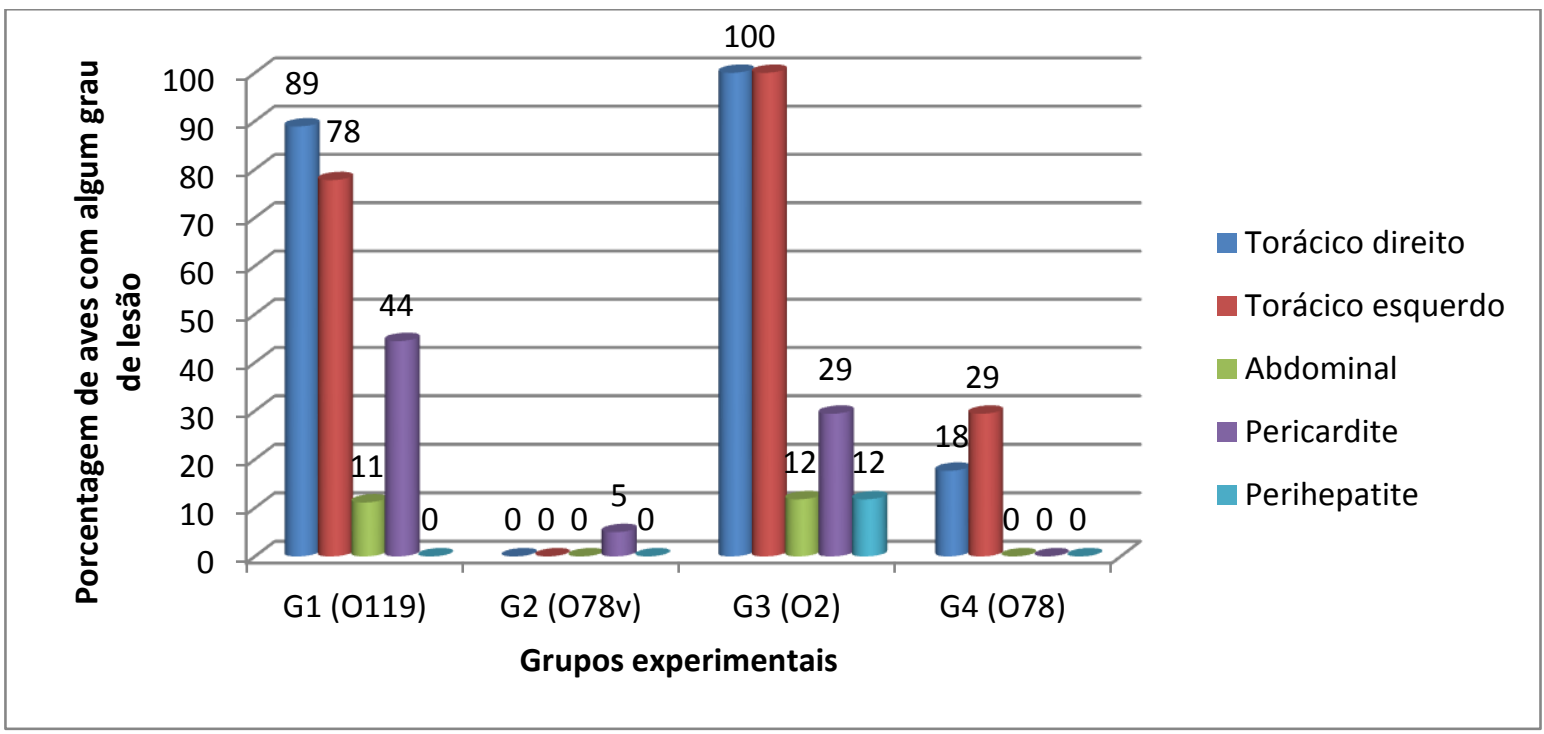

No grupo 1 (EC 341 - O119) as aves apresentaram redução de escores de lesão em todos os órgãos analisados, inclusive na serosa hepática não foi encontrada lesão aos 35 dias de idade.

As aves do grupo 3 (EC1695 - O2) mantiveram escores de lesão nos sacos aéreos torácicos direito e esquerdo, mas apresentaram declínio na ocorrência das lesões de sacos aéreos abdominais, pericárdio e serosa hepática.

A figura 4 representa a comparação entre as porcentagens de presença de escore de lesão entre o dia da infecção e o dia do término do experimento. 
Figura 4 - Comparação do escore de lesão entre o período pós-inoculação (aves que morreram) e o dia do sacrifício (35 dias) quanto à porcentagem de escore de lesão

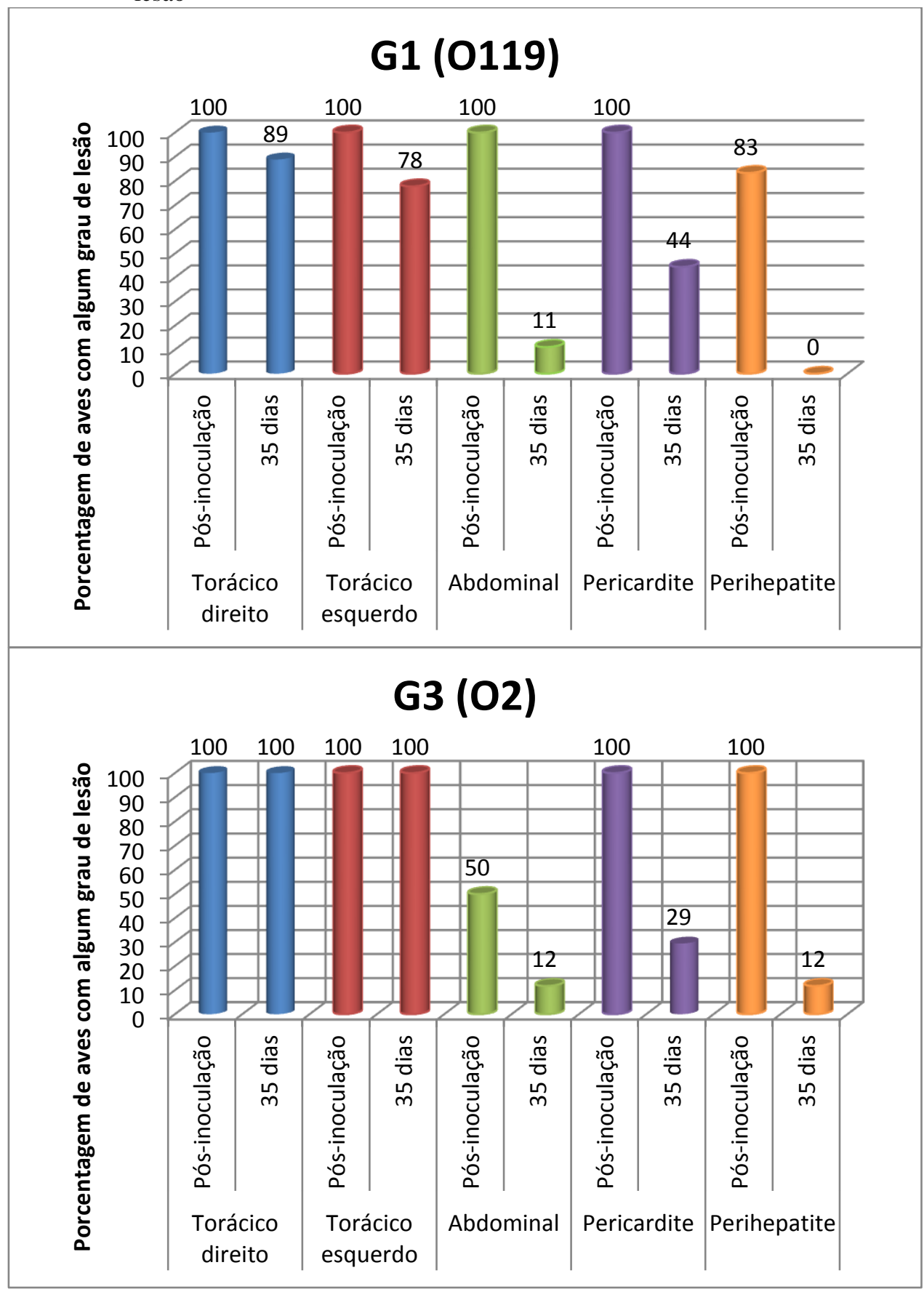


No último dia do experimento foi feito suabe dos órgãos para se reisolar Escherichia coli, todavia sem a possibilidade de diferenciar os sorogrupos usados e $E$. coli pertencente à microbiota. E. coli foi reisolada de 50\% das aves do grupo 1 (EC 341 - O119) e de todas as aves do grupo 4 (EC $1696-078$ ).

Na tabela 6 está representada a quantidade e a porcentagem de reisolamentos positivos para Escherichia coli. A figura 5 contém o gráfico com as porcentagens de E. coli reisoladas.

Tabela 6 - Quantidade de reisolamento positivo para E. coli nas aves dos grupos experimentais no dia do sacrifício (35 dias)

\begin{tabular}{ccc}
\hline Grupo & $\mathrm{N}^{\circ}$ positivos reisolamento & Porcentagem de positivos (\%) \\
\hline 1 (EC 341-O119) & $9 / 18$ & 50 \\
2 (vacinado) & $17 / 20$ & 85 \\
3 (EC 1695-O2) & $15 / 17$ & 88,2 \\
4 (EC 1696-O78) & $17 / 17$ & 100 \\
\hline
\end{tabular}

Figura 5 - Porcentagem de reisolamentos positivos para E. coli nos suabes de órgãos das aves no dia do sacrifício (35 dias)

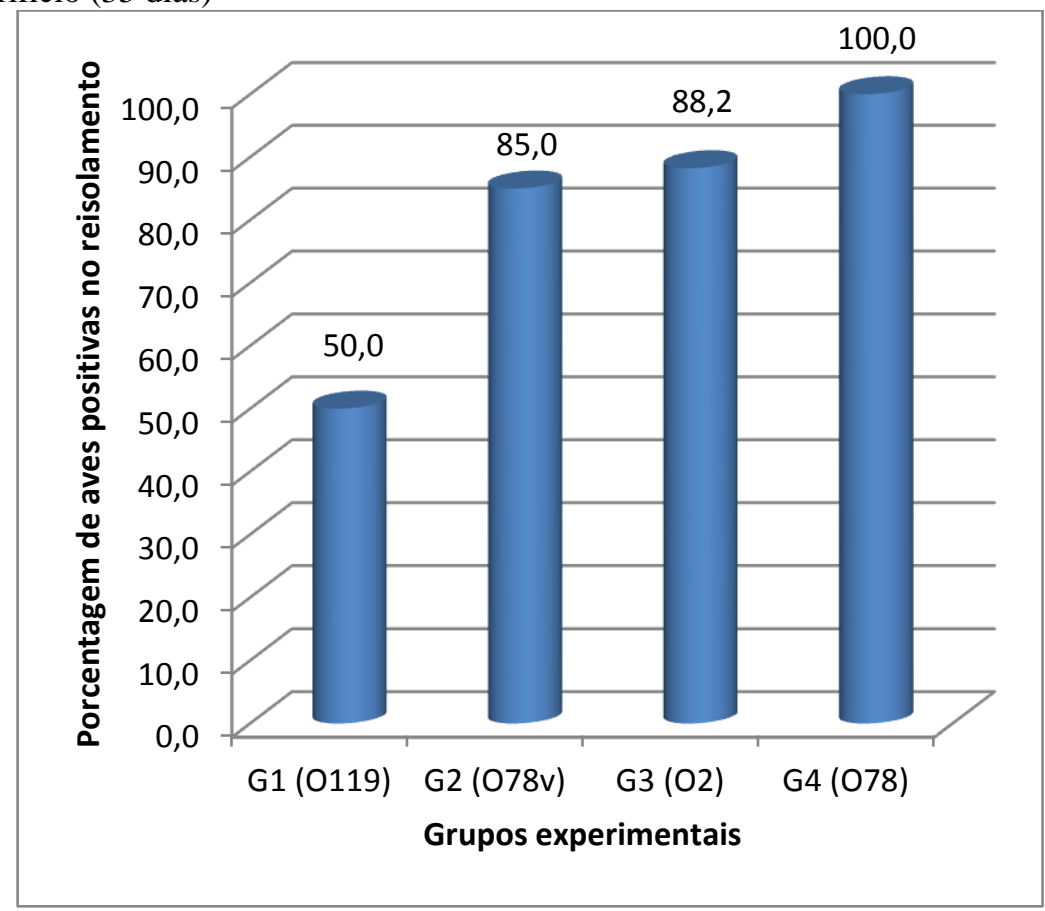

A figura 6 mostra ave necropsiada aos 24 dias de idade, pertencente ao grupo 3 (EC 1695 - O2) com lesões patológicas sugestivas de colibacilose, com placas de fibrina que recobrem todo o fígado, mediastino e pericárdio.

A figura 7 mostra ave aos 35 dias de idade pertencente ao grupo 3 (EC 1695 O2) e com lesões características de colibacilose, as lesões foram semelhantes às 
ocorridas aos 24 dias mostradas na figura 6 , contudo a placa de fibrina se mostra de consistência mais rígida e fina em relação às lesões da figura 6 .

Figura 6 - Ave aos 24 dias de idade pertencente ao grupo 3 (EC 1695 - O2)

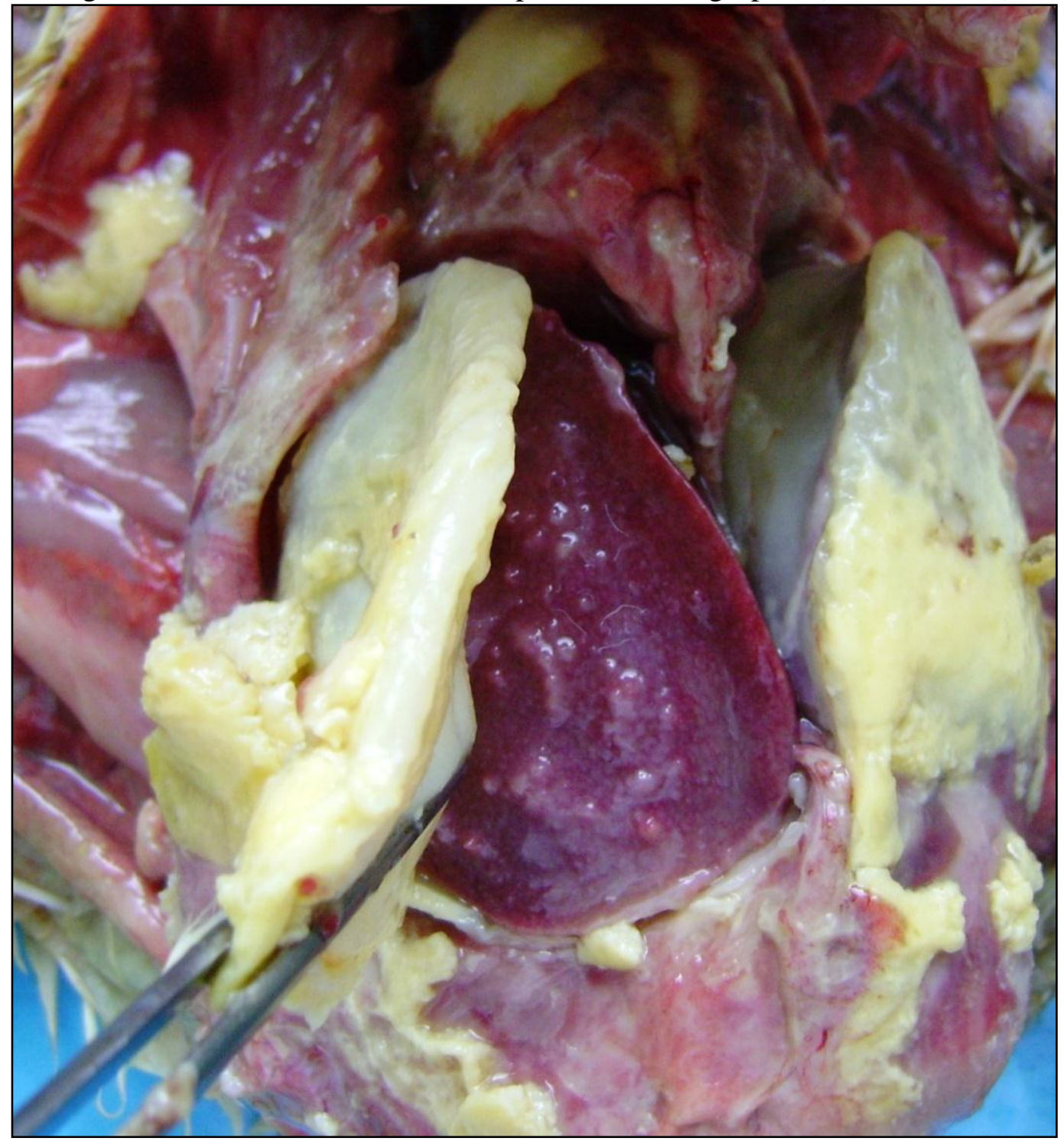


Figura 7 - Ave aos 35 dias de idade pertencente ao grupo 3 (EC 1695 - O2)

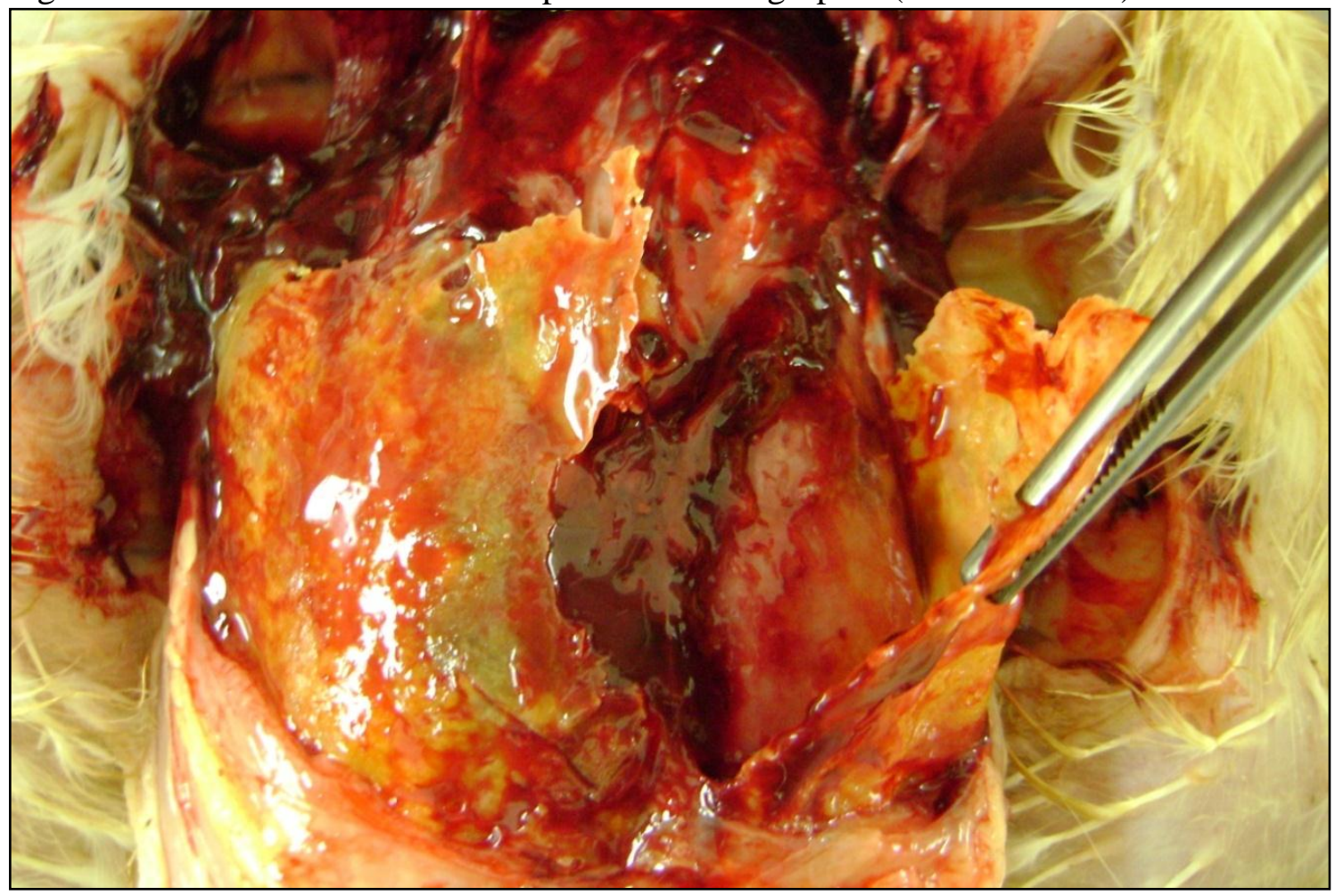

\subsection{ELETROFORESE EM GEL DE POLIACRILAMIDA}

Poucas proteínas foram obtidas de EC 1934, amostra vacinal (O78v), ocorreu uma maior frequência de proteínas com pesos moleculares entre 30 e $40 \mathrm{KDa}$. O sorogrupo O2 (EC 1695) produziu a menor variabilidade de proteínas, enquanto a maior foi produzida pelo sorogrupo O119 (EC 341). A figura 8 mostra a coloração pelo Coomassie Blue ou pelo nitrato de prata das amostras estudadas. 
Figura 8 - Perfil eletroforético de proteínas obtidas de E. coli em gel de acrilamida 12\% corado com Coomassie Blue (A) ou nitrato de prata (B)
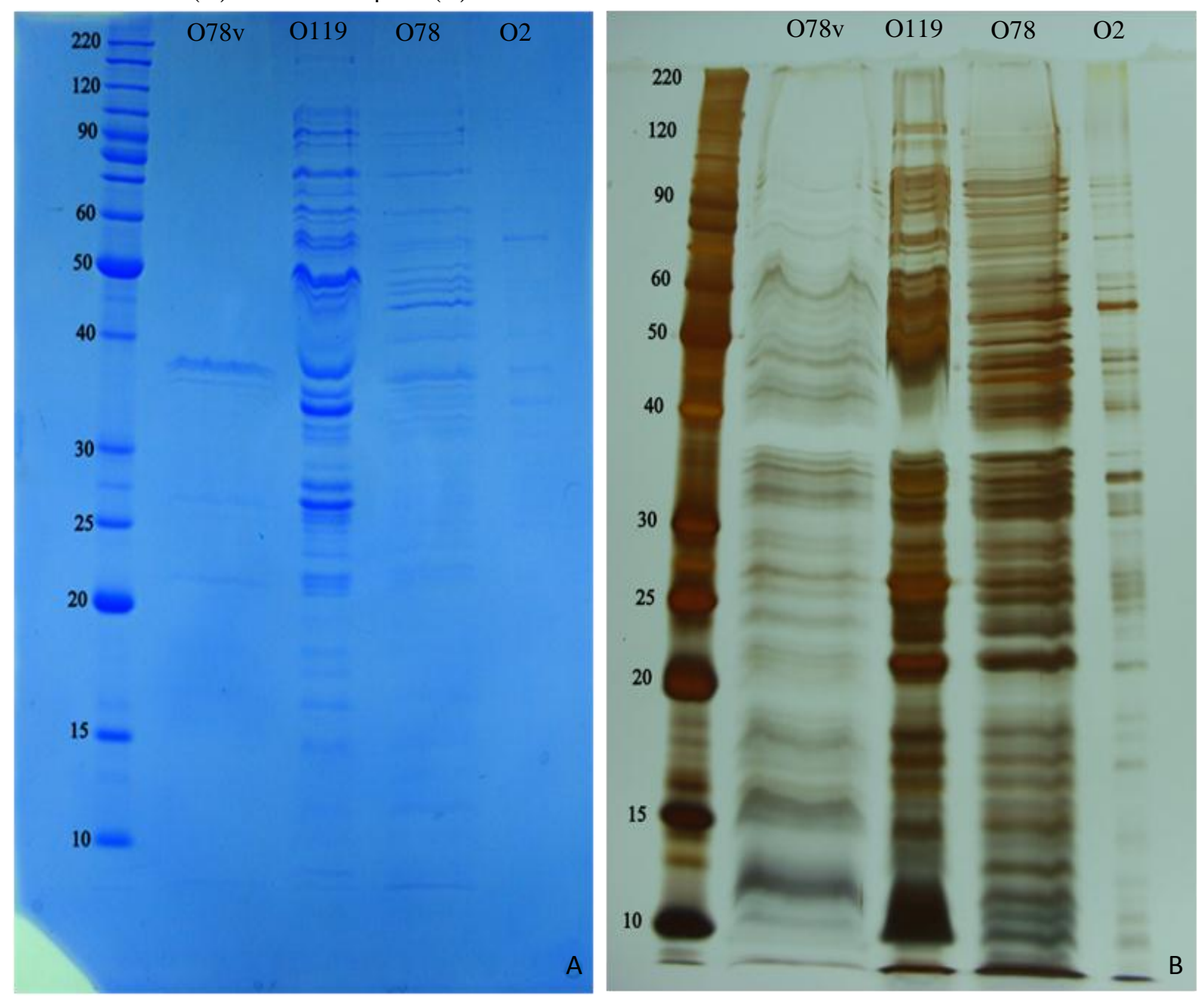

\subsection{WESTERN BLOT}

As proteínas obtidas dos diferentes sorogrupos foram analisadas na forma de preparativo.

A análise das proteínas do sorogrupo O2 (EC 1695), com os soros dos diferentes grupos experimentais revelou a presença de anticorpos para muitas proteínas de E. coli. No entanto, as proteínas de 71,3 KDa e 68,5 KDa reagiram com anticorpos encontrados nos soros das aves infectadas com O119, O78v e com o soro homólogo. A proteína de $28,3 \mathrm{KDa}$ reagiu com anticorpos presentes nos soros das aves infectadas com $\mathrm{O} 78, \mathrm{O} 78 \mathrm{v}$ e homológo. A proteína de 45,6 KDa reagiu com 
anticorpos dos soros das aves infectadas com O119, O78v, O2 e O78, portanto uma proteína comum a estes sorogrupos.

Na figura 9 se encontra a membrana com o perfil de proteínas do sorogrupo O2

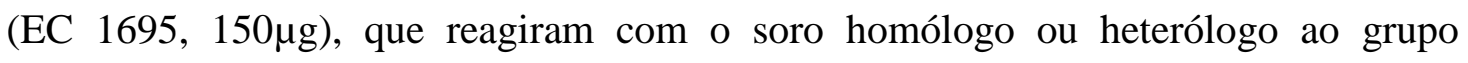
experimental, o anticorpo primário foi diluído em 1:200 e o anticorpo secundário antiIgG em 1:2000. 
Figura 9 - Reação de western blot em preparativo de proteínas do sorogrupo O2 (EC 1695) reagido com pool de soros dos diferentes grupos de aves infectadas experimentalmente e com soros de aves saudáveis

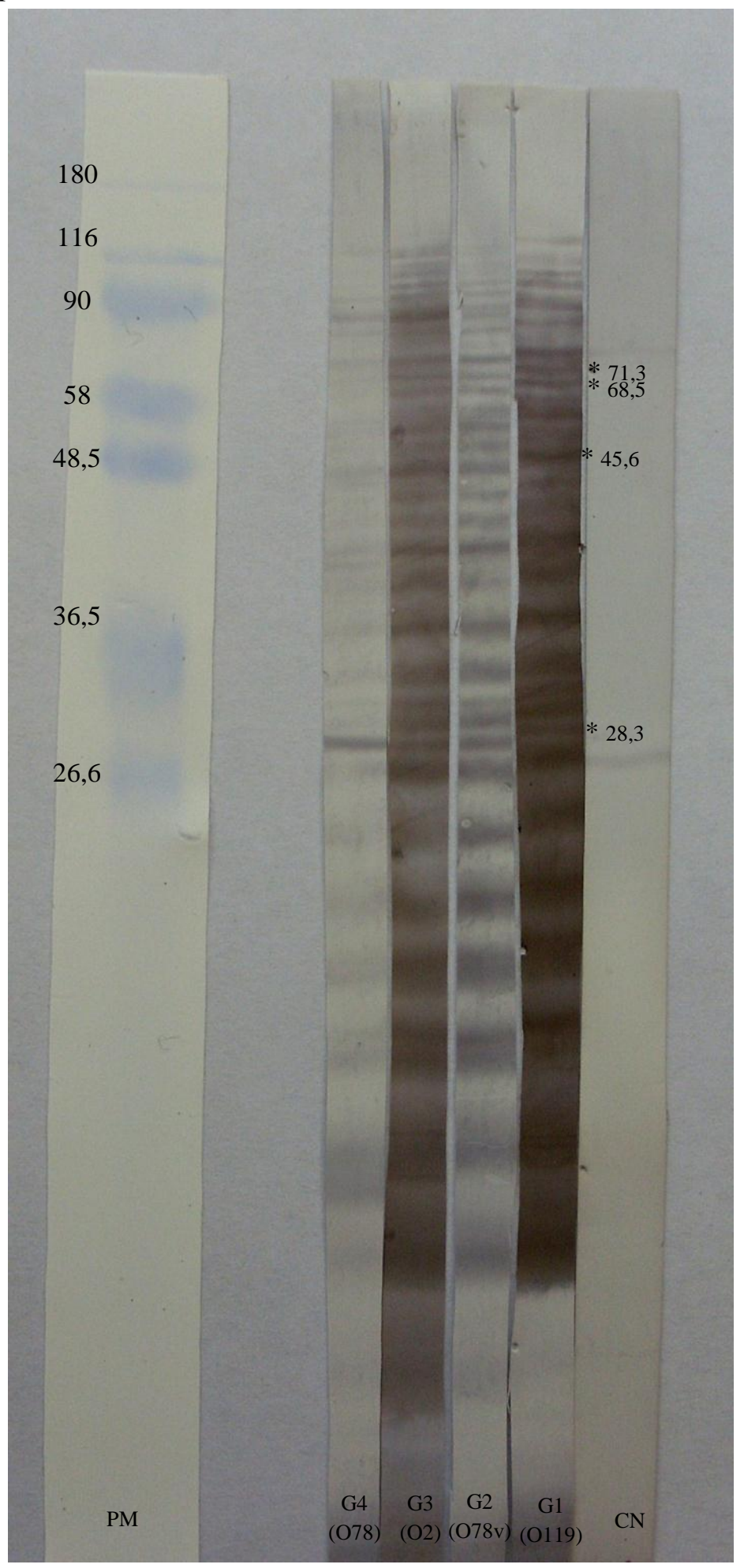


A reação de western blot com o perfil de proteínas do sorogrupo O78 (EC1696) detectou que a proteína de 21,8 KDa reagiu com anticorpos presentes no soro das aves infectadas com o sorogrupo $\mathrm{O} 2$ e O78. A proteína de 39,4 KDa reagiu apenas com anticorpos de aves infectadas com o sorogrupo O119. As proteínas de 91,6 KDa, 67,9 KDa e 30,4 KDa reagiram com anticorpos presentes no soro de aves infectadas com as amostras $\mathrm{O} 2$ e $\mathrm{O} 119$.

A figura 10 mostra a membrana com as proteínas obtida do sorogrupo O78 (EC 1696, $5.000 \mu \mathrm{g}$ ), que reagiram com o soro homólogo ou heterólogo ao grupo experimental, o anticorpo primário foi diluído em 1:400 e o anticorpo secundário anti-IgG em 1:3000. 
Figura 10 - Reação de western blot em preparativo de proteínas do sorogrupo O78 (EC 1696) reagido com pool de soros dos diferentes grupos de aves infectadas experimentalmente e com soros de aves saudáveis

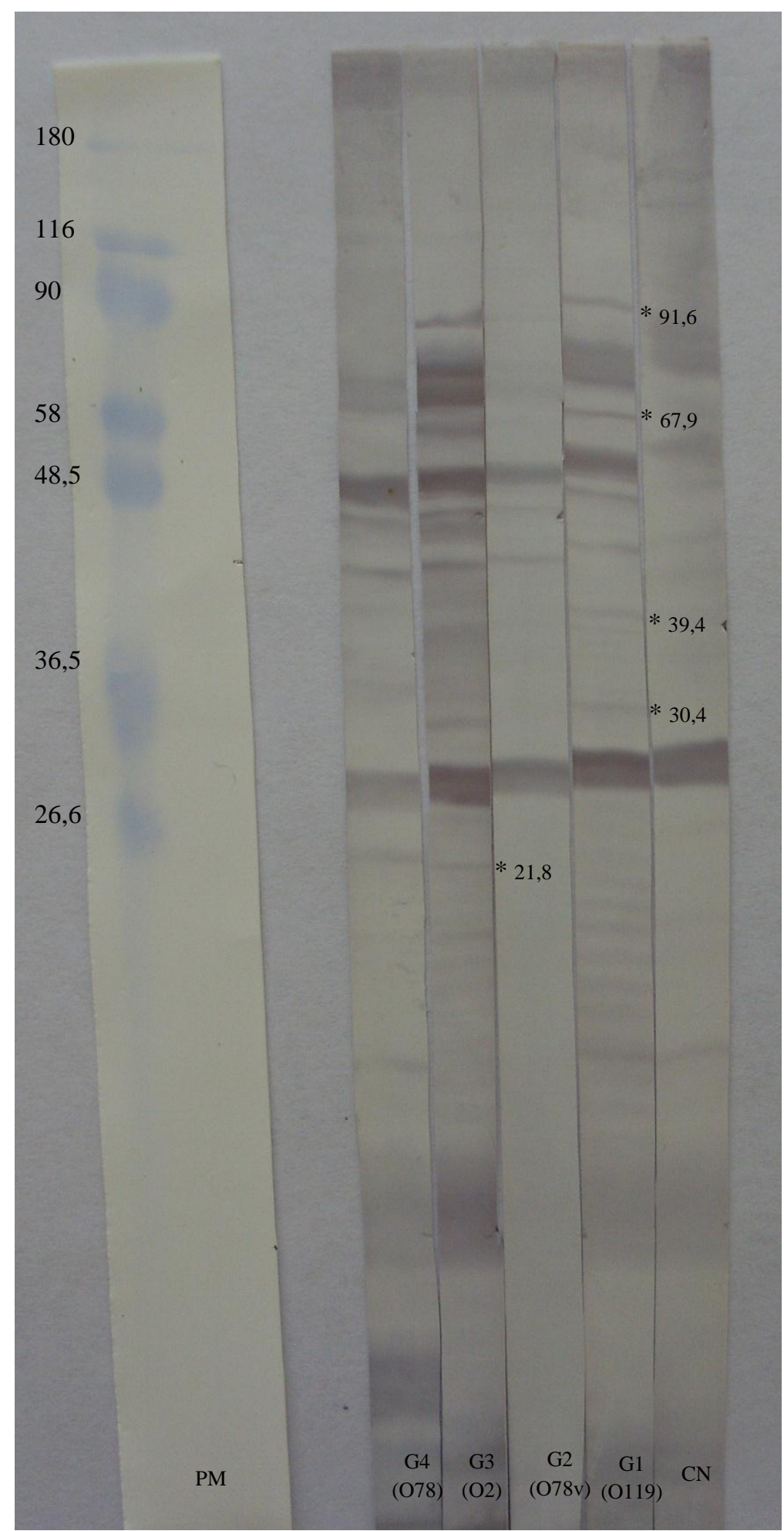


O perfil eletroforético das proteínas obtidas da amostra EC341 (O119) foi submetido à reação de Western blot com os soros de aves infectadas experimentamente e com os soros de aves normais. As proteínas de 11,7 KDa, 8,6 KDa 7,2 KDa, 6,0 KDa e 5,0 KDa apenas reagiram com os anticorpos do soro homólogo O119 (EC 341). A proteína de 13,3 KDa reagiu com os anticorpos do soro homólogo e com o soro das aves infectadas com a amostra O2 (EC 1695), O78 (EC 1696) e O78v (EC 1934).

A figura 11 mostra a membrana com as proteínas obtidas do sorogrupo O119 (EC 341, $5.000 \mu \mathrm{g}$ ), que reagiram com o soro homólogo ou heterológo ao grupo experimental, o anticorpo primário foi diluído em 1:400 e o anticorpo secundário anti-IgG em 1:3000. 
Figura 11 - Reação de western blot em preparativo de proteínas do sorogrupo O119 (EC 341) reagido com pool de soros dos diferentes grupos de aves infectadas experimentalmente e com soros de aves saudáveis

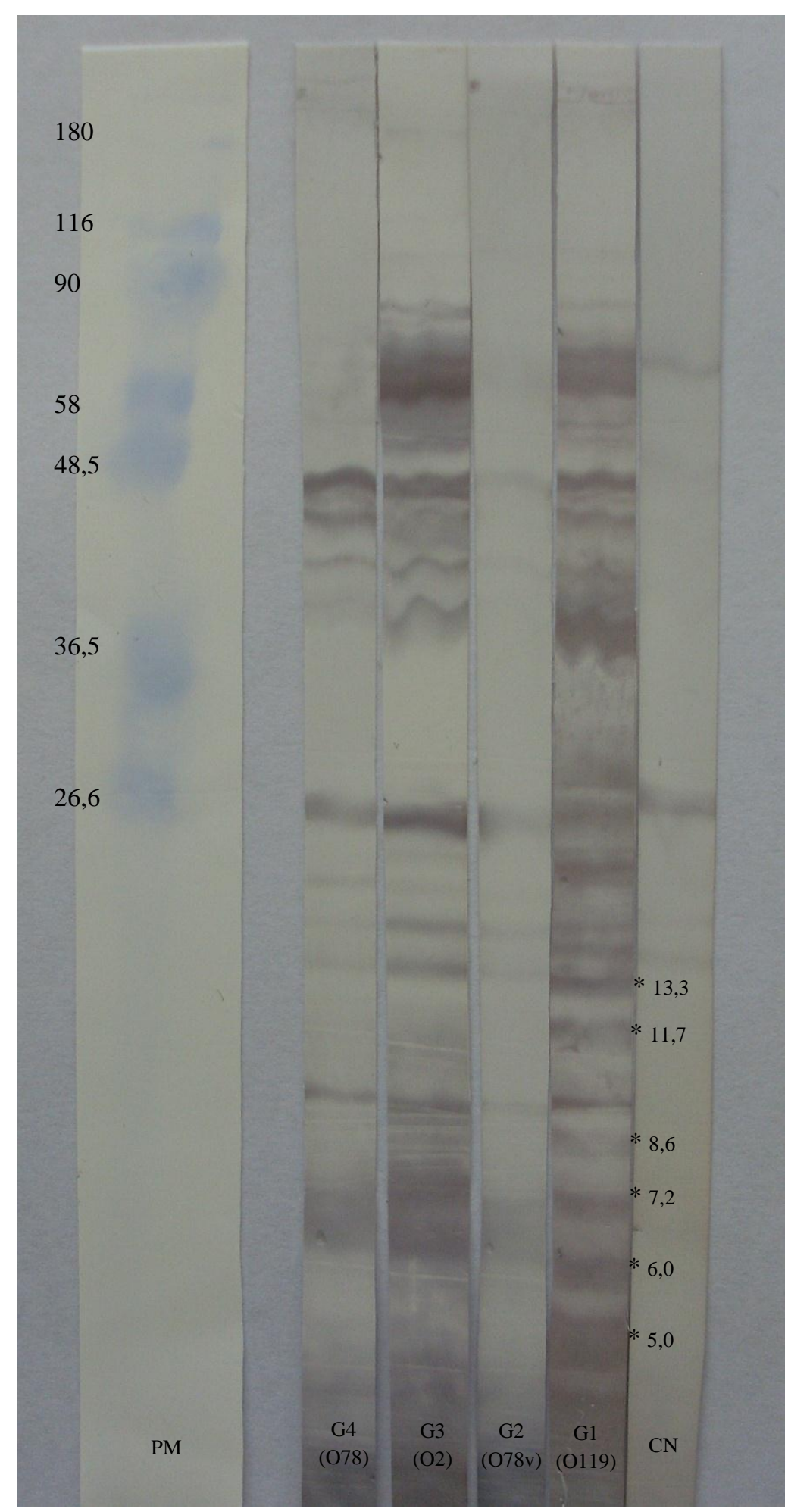

A reação de western blot foi realizada com as proteínas obtidas da amostra EC1934, amostra vacinal (O78), com os soros obtidos das aves infectadas experimentalmente e com os soros das aves saudáveis. Foi possível notar apenas uma banda proteica de 24,3 KDa e que se 
mostrou inespecífica, pois ocorreu também no soro das aves SPF. Em todos os preparativos de diferentes sorogrupos ocorreu uma proteína inespecífica com peso molecular entre 24 e 27,4 KDa. A figura 12 mostra a membrana com as proteínas obtidas do sorogrupo O78 de origem vacinal $(\mathrm{EC} 1934,10.000 \mu \mathrm{g})$, que reagiram com o soro homólogo ou heterólogo ao grupo experimental, o anticorpo primário foi diluído em 1:100 e o anticorpo secundário antiIgG em 1:3000. 
Figura 12 - Reação de western blot em preparativo de proteínas do sorogrupo O78 de origem vacinal (EC 1934) reagido com pool de soros dos diferentes grupos de aves infectadas experimentalmente e com soros de aves saudáveis

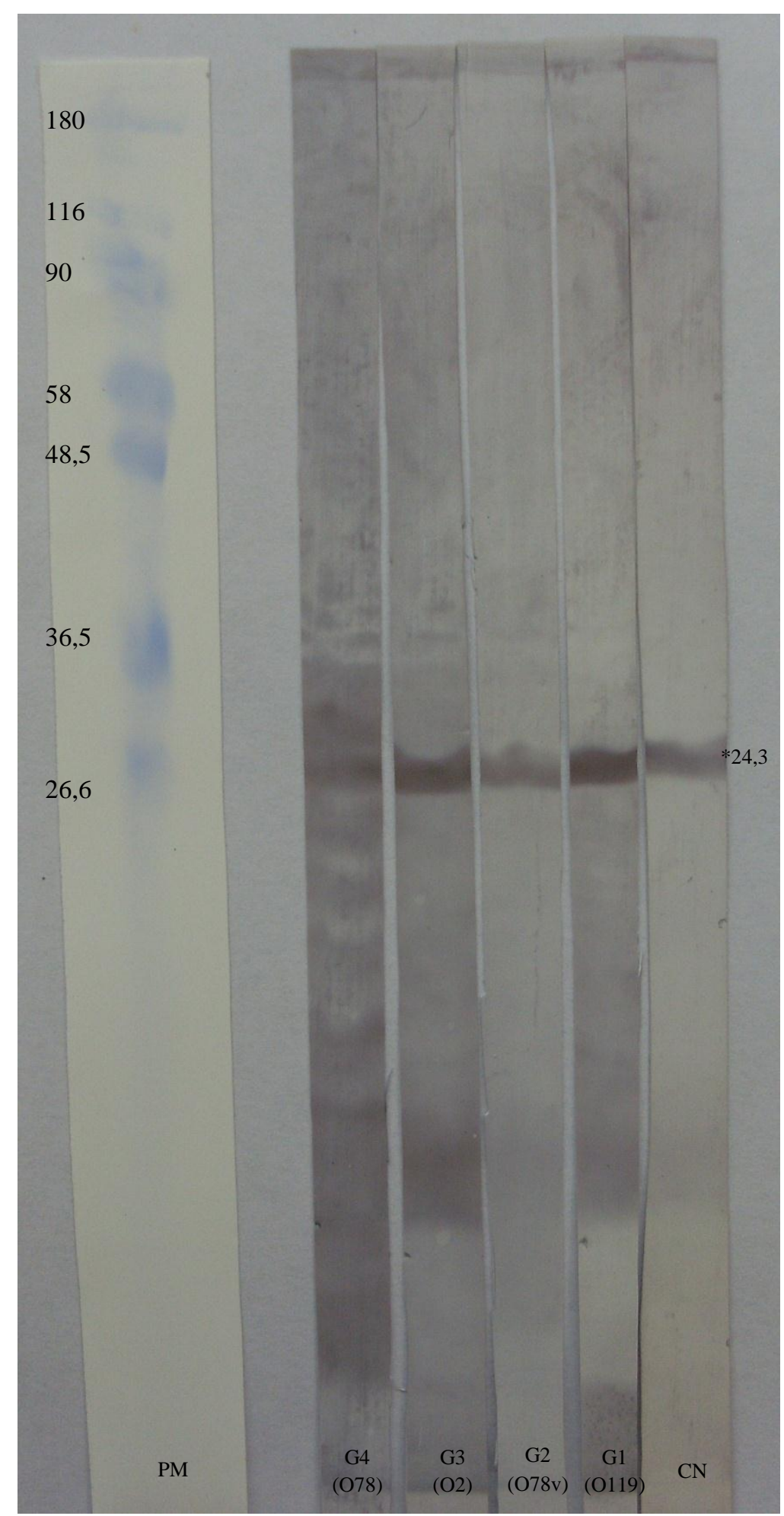




\section{DISCUSSÃO}

A colibacilose é a infecção bacteriana que mais causa mortalidade e morbidade para a avicultura (CHANSIRIPORNCHAI, 2009), visto que facilita a infecção por outros microorganismos agravando quadros clínicos e prejudicando a qualidade da carcaça. Diante da importância desta enfermidade e somado ao fato da crescente resistência bacteriana a antimicrobianos, é importante o uso de outros métodos profiláticos, tais como vacinas, todavia as vacinas contra colibacilose apresentam falhas (RADHOUANI et al., 2012), visto que dificilmente causam resposta imune cruzada para diferentes sorotipos. Assim, encontrar proteínas comuns à maioria dos sorotipos patogênicos é de grande importância e estas podem ser encontradas entre as proteínas de membrana externa, secretadas ou totais.

Estudos com proteínas de membrana externa para a indução de imunidade contra APEC tem-se mostrado eficiente. Em estudo com a ISS (LYNNE et al., 2012) e fímbria P (OH et al., 2011), em ambos, houve resposta imunológica protetora humoral e celular contra diferentes sorogrupos.

Ainda não há estudos com as proteínas secretadas por E. coli para a investigação de proteínas protetoras, mas há trabalhos com Salmonella spp. onde as proteínas secretadas se mostraram eficazes na indução de imunidade, como no trabalho de Hur e Lee (2011) em que se inseriu um gene produtor de toxina termo lábil de E. coli com a finalidade de aumentar a imunidade contra Salmonella. As proteínas secretadas são importantes, pois participam de mecanismos de toxicidade, sistema de sinalização entre células (quorum sensing) e também como indicativo de fase de crescimento bacteriano (CORDWELL; NOUWENS; WALSH, 2001).

Várias proteínas foram obtidas após o cultivo dos diferentes sorogrupos de Escherichia coli em meio casaminoácido e levedura. Não é possível afirmar que na forma de extração usada neste estudo existam apenas proteínas secretadas, pois no processo de filtragem ou mesmo durante o crescimento bacteriano, podem ter ocorrido proteínas intracelulares e de membrana como flagelos, visto que pode haver lise bacteriana por ação de proteases degradativas (CORDWELL; NOUWENS; WALSH, 2001). No entanto, é possível considerar que proteínas secretadas estejam presentes entre as proteínas obtidas.

Houve diferenças no perfil de proteínas extraídas dos diferentes sorogrupos de E. coli e também na reatividade detectada pelo método de western blot. O método de eletroforese aliado ao western blot é adequado para uma triagem de proteínas importantes na infecção, 
todavia há limitações como cultivar o micro-organismo patogênico in vitro de modo a reproduzir a realidade da infecção in vivo. Assim como, o fato de haver proteínas que ocorrem apenas em determinadas fases da infecção e que muitas vezes não são detectadas (WONGSAWAN et al., 2010). Ao se detectar um antígeno que realize ligação antígenoanticorpo quando reagido com soro de animais doentes, mas não de saudáveis, é possível que esta proteína seja importante na infecção (CHEETHAM; KATZ, 1995).

Em estudo de Piechaczek et al. (2000) as proteínas produzidas por sorogrupos de $E$. coli uropatogênicas foram comparadas e observaram que proteínas distintas eram produzidas entre estas bactérias. Como existem diferentes ilhas de patogenicidade e variação de perfil proteico entre sorogrupos da mesma espécie de bactéria ou fungo, foi sugerido que há diferenças no processo infeccioso, inclusive quanto aos fatores de virulência (JOBBINS et al., 2010).

As proteínas semelhantes entre diferentes sorotipos patogênicos da mesma espécie indicam que estas apresentam potencial para serem usadas na composição de vacinas. Aquelas produzidas em apenas uma fase da infecção poderiam ser usadas como método diagnóstico e prognóstico (LI et al., 2011).

A bactéria de sorotipo O2 (EC 1695) cultivada em meio de cultura casaminoácido e levedura produziu proteínas que fizeram ligações antígeno-anticorpo específicas em maior quantidade quando comparada com o perfil de proteínas produzidas pelos outros sorogrupos estudados. Este resultado indica que o meio de cultura estimulou a produção de proteínas pela bactéria que também foram produzidas durante a infecção. A mortalidade das aves deste grupo foi baixa, porém houve lesão em $100 \%$ das aves nos sacos aéreos torácicos direito e esquerdo, tanto após a inoculação quanto no dia do sacrifício. Houve lesão em saco aéreo abdominal, pericárdio e serosa hepática. No entanto, quando comparadas as lesões de uma ave que morreu após o desafio com aquelas do dia do sacrifício, a frequência e a gravidade dessas foi reduzida. A concentração bacteriana usada foi suficiente para causar a enfermidade sem causar alta mortalidade. A proteína de 45,6 KDa deste sorogrupo apresentou ligação antígenoanticorpo com todos os soros de aves desafiadas, assim, esta proteína pode ser importante na colibacilose, e de acordo com LI et al., 2011 esta pode ter um potencial para uma vacina de subunidade.

E. coli do sorogrupo O78 (EC 1696) produziu poucas proteínas específicas capazes de fazer ligação antígeno-anticorpo com os anticorpos IgG presentes no soro das aves doentes. Houve a produção de cinco proteínas específicas quando esta bactéria foi cultivada no meio de cultura casaminoácido e levedura. Este resultado sugere que o meio de cultura usado neste 
estudo não foi capaz de modular a síntese de proteínas por este sorotipo. O soro das aves infectadas com o sorogrupo O119 (EC 341) quando reagido por western blot com as proteínas do obtidas do sorogrupo O78 (EC 1696) apresentou apenas uma ligação antígeno-anticorpo específica com uma proteína de 39,4 KDa e encontrada apenas na reação com este soro. Dessa forma, este resultado revela que esta proteína deve ter sido produzida in vivo apenas com esta amostra, o que sugere a particularidade do processo infeccioso deste sorogrupo (JOBBINS et al., 2010). Este grupo não apresentou mortalidade no período pós-inoculação e no dia do sacrifício apenas algumas aves apresentaram lesões nos sacos aéreos torácicos direito $(\mathrm{n}=$ 3/14) ou esquerdo $(n=5 / 14)$, não houve lesão nos sacos aéreos abdominais, pericárdio ou serosa hepática. Houve reisolamento de E. coli em $100 \%$ das aves. Diante da baixa morbidade, mortalidade e lesões patológicas macroscópicas, trata-se de uma bactéria de menor virulência, embora seja capaz de causar enfermidade, dada a alta taxa de reisolamento. Em estudo de Wongsawan et al. (2010) foi observado que ao comparar duas cepas de Streptococcus suis, a menos virulenta foi capaz de produzir mais proteínas que fizeram ligações específicas com os anticorpos do soro dos enfermos. Neste estudo estes resultados não foram corroborados, o que pode ser explicado pelo fato de o meio de cultura utilizado não ter estimulado a produção de proteínas específicas da infecção com este sorogrupo.

As proteínas da bactéria EC341 (sorogrupo O119) produzidas em meio casaminoácido e levedura quando reagidas com soros não homólogos se mostraram específica apenas para uma proteína de $13,3 \mathrm{KDa}$, as demais proteínas específicas reagiram apenas com o soro da ave infectada com O119. Este resultado sugere que apenas esta proteína estivesse presente no soro das aves infectadas com os demais sorogrupos estudados, embora esta bactéria tenha produzido grande variabilidade de proteínas (figura 8). O soro dessas aves quando reagidos com as proteínas de outros sorotipos revelou muitas ligações específicas com estas proteínas, demonstrando que na infecção com o sorogrupo O119 ocorreu a produção de proteínas que foram obtidas dos outros sorogrupos.

As aves infectadas com o sorogrupo O119 também foram as que apresentaram maior porcentagem de mortalidade no período pós-inoculação. Quanto às lesões aos 35 dias de idade, elas ocorreram em todas as aves nos sacos aéreos torácicos e abdominais e pericárdio e 83\% na serosa hepática. Estes resultados demonstram que esta amostra é patogênica, uma vez que houve mortalidade e lesões nos diferentes órgãos estudados. Este grupo de aves foi o que apresentou menor taxa de reisolamento positivo para Escherichia coli. Após a invasão de um agente infeccioso, o hospedeiro inicia uma série de eventos com o objetivo de controlar e eventualmente resolver a infecção. A resposta imediata do hospedeiro a patógenos invasores é 
a sua eliminação através da resposta inflamatória e a ativação apropriada da resposta imune adquirida, eventos que são coordenados pelos mecanismos de resposta inata do hospedeiro (JANEWAY, MEDZHITOV, 2002). Leucócitos polimorfonucleares, entre estes, os heterófilos, são células de grande importância na imunidade inata, pois atuam eliminando micro-organismos após a fagocitose (JUUL - MADSEN et al., 2008). Como a coleta da amostra foi realizada passando o suabe na superfície de órgãos, onde havia cáseos, é possível que a bactéria tenha morrido em consequência de uma ativação imunológica, pois a presença de cáseo indica que ocorreu um processo inflamatório, com morte de heterófilos e/ou macrófagos (JUUL - MADSEN et al., 2008). Neste grupo de aves ocorreu ativação imunológica, com a síntese de anticorpos para várias proteínas estudadas, pois o pool de soros reagiram com maior número de ligações antígeno-anticorpo com proteínas de diferentes sorotipos. Assim, as aves deste grupo produziram in vivo as mesmas proteínas que o meio de cultura estimulou a produção in vitro, estas eram imunogênicas e induziram a síntese de anticorpos pela ave. Diante da presença de proteínas específicas produzidas na infecção encontradas apenas com soro homólogo, alta mortalidade e baixa taxa de reisolamento, é provável que esta bactéria possua fatores de virulência que as outras estudadas não possuam. Embora tenha havido a proteína de $13,3 \mathrm{KDa}$ que reagiu com os anticorpos de todas as aves desafiadas ou vacinadas, a diferença neste perfil proteico revelou uma particularidade no processo infeccioso e também dos sinais clínicos, conforme sugerido por WONGSAWAN et al. (2010).

O soro obtido das aves vacinadas com Poulvac E.coli, $\left(\right.$ Pfizer $\left.^{\circledR}\right)$ apresentaram poucas ligações antígeno-anticorpo com as proteínas provenientes dos sorogrupos patogênicos. A maior frequência de ligação ocorreu quando reagido com o soro das aves infectadas com o sorotipo O2. Isto pode ser devido ao fato de no alojamento, as aves vacinadas ficarem ao lado das aves do grupo infectado com $\mathrm{O} 2$.

Inicialmente acreditou-se que a bactéria de origem vacinal, devido à mutação no gene responsável por coordenar a síntese de aminoácidos essenciais produziria poucas proteínas, e por isso não ocorreriam muitas ligações antígeno-anticorpo no western blot. No entanto, após a coloração do gel de eletroforese por nitrato de prata, detectou-se um maior número de bandas proteicas, muitas delas presentes também na amostra O78, porém estas bandas se encontram em baixa concentração, e talvez no processo de transferência do western blot não tenha havido concentração suficiente para ocorrer ligações antígeno-anticorpo específicas perceptíveis. 
Os soros das aves vacinadas não apresentaram ligação antígeno-anticorpo específica quando reagido com as proteínas obtidas de EC 1696 (O78) que pertence ao mesmo sorogrupo. Considerando as condições laboratoriais usadas neste estudo, é possível sugerir que o comportamento da cepa vacinal in vitro foi diferente daquele in vivo, ou seja, que apenas nas condições in vitro foram induzidas pelo meio de cultura a produção de proteínas que reagiram com o soro de aves doentes e de aves livres de patógenos específicos. Não houve mortalidade no grupo de aves vacinadas e apenas uma ave apresentou lesão moderada no pericárdio, o que indica que mesmo na presença de sorotipos de Escherichia coli distintos, a vacina foi capaz de proteger a ave, visto que uma das formas de transmissão ocorre por contato direto ou indireto com aves doentes (BARNES; NOLAN; VAILLANCOURT, 2008). Apenas a proteína de $24,3 \mathrm{KDa}$ reagiu com os anticorpos de todos os soros testados, inclusive do grupo controle.

As proteínas secretadas pela bactéria O2 (EC 1695) apresentaram várias ligações antígeno-anticorpo específicas e comuns aos soros das aves infectadas com O119, O78 e vacinada. 


\section{CONCLUSÕES}

$\checkmark$ Há diferenças entre os sorogrupos quanto à patogenicidade e manifestação clínica, observado também pelo fato de haver ligações antígeno-anticorpo específicas de soros homólogos.

$\checkmark$ Há diferenças nos perfis de proteínas extraídas dos diferentes sorogrupos testados e também diferenças na reatividade detectada pelo western blot.

$\checkmark$ O meio de cultura casaminoácido e levedura estimulou a produção de proteínas, com perfil proteico diferente entre os sorogrupos de Escherichia coli estudados.

$\checkmark$ A vacina Poulvac E.coli (Pfizer ${ }^{\circledR}$ ) se mostrou eficaz na proteção do grupo vacinado, mesmo que as aves tenham sido criadas próximas a aves infectadas com outros sorogrupos diferentes do vacinal.

$\checkmark$ O antígeno que apresentou ligação antígeno-anticorpo com todos os soros das aves desafiadas e vacinadas possui 45,6 KDa e foi produzido pela bactéria de sorotipo $\mathrm{O} 2$ (EC 1695).

$\checkmark$ A proteína de 13,3 KDa extraída da bactéria EC 341 (O119) apresentou ligações com anticorpos dos soros das aves desafiadas e vacinadas.

$\checkmark$ O meio de cultura casaminoácido e levedura não foi eficaz para estimular a produção de proteínas importantes na imunização in vivo pela vacina Poulvac E.coli (Pfizer ${ }^{\circledR}$ ) dada a baixa quantidade de ligações antígeno-anticorpo. 


\section{REFERÊNCIAS}

ANTÃO, E. M. Identification of avian pathogenic E.coli (APEC) genes important for the colonization of the chicken lung and characterization of the novel ExPEC adhesin $I$. 2010. 139 f. Dissertação (Doutorado em Biologia) - Faculdade de Humboldt, Berlin, 2010.

ASTOLFI-FERREIRA, C. S. Detecção de imunoglobulinas séricas a proteínas de Salmonella entérica sorotipo Enteritidis em aves infectadas experimentalmente. 2001. 85 f. Tese (Doutorado em Patologia Experimental e Comparada) - Faculdade de Medicina Veterinária e Zootecnia, Universidade de São Paulo, São Paulo, 2001.

AYALEW, S.; CONFER, A.; HARTSON, S.; SHRESTHA, B. Immunoproteomic analyses of outer membrane proteins of Mannheimia haemolytica and identification potential vaccines candidates. Proteomics, v. 10, p. 2151-2164, 2010.

BARNES, H. J.; NOLAN, L. K.; VAILLANCOURT, J. P. Colibacillosis. In: SAIF, Y. M.; FADLY, A. M.; GLISSON, J. R.; McDOUGALD, L. R.; NOLAN, L. K.; SWAYNE, D. E. Diseases of Poultry. 12. ed. Florida State: Blackwell, 2008. p. 691-737.

BLATTNER, F. R.; PLUNKET III, G.; BLOCH, C. A.; PERNA, N. T.; BURLAND, V.; RILEY, M.; COLLADO-VIDES, J.; GLASNER, J. D.; RODE, C. K.; MAYHEW, G. F.; GREGOR, J.; DAVIS, N. W.; KIRKPATRICK, H. A.; GOEDEN, M. A.; ROSE, D. J.; MAU, B.; SHAO, Y. The complete genome sequence of Escherichia coli K-12. Science, v. 277, p. 1453-1462, 1997.

BLUM, H.; BEIER, H.; GROSS, H. J. Improved silver stain of plant proteins, RNA and DNA in polyacrylamide gels. Electrophoresis, v. 8, p. 93-99, 1987.

BOLLAG, M.; ROZYCKI, M. D.; EDELSTEIN, S. J. Preparation for protein isolation. In: BOLlAG, M.; ROZYCKI, M. D.; EDELSTEIN, S. J. Protein Methods. 2. ed. Nova York: Wiley-Liss, 1996. p. 1-26.

CAMARGO, Z. P.; TABORDA, C. P.; RODRIGUES, E. G.; TRAVASSOS, L. R. The use of cell-free antigen of Paracoccidioides brasiliensis in serological test. Journal of medical and Veterinary Mycology, v. 29, p. 31-38, 1991.

CASH, P. Proteomics in medical microbiology. Electrophoresis, v. 21, p. 1187-1201, 2001. 
CHANSIRIPORNCHAI, V. R. N. The efficacy of Escherichia coli AroA- live vaccine in broilers against Avian E.coli serotype $\mathrm{O} 78$ infection, Thai Journal of Veterinary Medicine, v. 39, n. 4, p. 337-342, 2009.

CHEETHAM B.F.; KATZ, M.E. A role for bacteriophages in the evolution and transfer of bacterial virulence determinants. Molecular Microbiology, v.18, n.2, p. 201-208, 1995.

CORDWELL, S. J.; NOUWENS, A. S.; WALSH, B. J. Comparative proteomics of bacterial pathogens. Proteomics, v. 1, p. 461-472, 2001.

DHO-MOULIN, M.; BOSCH, J. F.; GIRARDEAU, J. P.; BRÉE, A.; BARAT, T.; LAFONT, J. P. Surface antigens from Escherichia coli $\mathrm{O} 2$ and $\mathrm{O} 78$ strains of avian origin. Infection and Immunitiy, v. 58, n. 3, p. 740-745, 1990.

DRIESSEN, A. J. M.; NOUWEN, N. Protein translocation across the bacterial cytoplasmic membrane. Annual Review of Biochemistry, v. 77, p. 643-667, 2008.

ECONOMOU, A. Following the leader: bacterial protein export through the Sec pathway. Trends in Microbiology, v. 7, n. 8, p. 315-320, 1999.

EMERY, D. A.; NAGARAJA, K. V.; SHAW, D. P.; NEWMAN, J. A.; WHITE, D. G. Virulence factors of Escherichia coli associated with colisepticemia in chickens and turkeys. Avian Diseases, v. 36, p. 504-511, 1992.

EWERS, C.; ANTÃO, E. M.; DIEHL, I.; PHILIPP, H.; WIELER, L. H. Intestine and environment of the chicken as reservoirs for extraintestinal pathogenic Escherichia coli strains with zoonotic potential. Applied and Environmental Microbiology, v. 75, n. 1, p. 184-192, 2009.

FANTINATTI, F. Estudos biológicos e genéticos de amostras de Escherichia coli de origem aviária. 1991. 91 f. Dissertação (Mestrado em Ciências) - Instituto de Biologia, UNICAMP, Campinas, 1991.

FERREIRA, A. J. P.; KNÖBL, T. Colibacilose. In: BERCHIERI JÚNIOR, A.; SILVA, E. N.; DI FÁBIO, J.; SESTI, L.; ZUANAZE, M. A. F. Doenças das Aves, 2. ed. Campinas: FACTA, 2009. p. 457-471.

FINLAY, B. B.; FALKOW, S. Common themes in microbial pathogenicity revisited. Microbiology and Molecular Biology Reviews, v. 61, n. 2, p. 136-169, 1997. 
GARFIN, D. E. One-dimensional electrophoresis. In: BURGESS, R. R.; DEUTSCHER, M. P. Methods in enzymology - Guide to protein purification. 2. ed. United States: Elsevier, 2009. p. 497-514.

GOREN, E. Observations on experimental infection of chicks with Escherichia coli. Avian Pathology, v. 7, n. 2, p. 213-224, 1978.

HACKER, J.; KAPER, J. B. Pathogenicity islands and the evolution of microbes. Annual Review of Microbiology, v. 54, p. 641-679, 2000.

HAN, M. J.; LEE, S. Y. The Escherichia coli proteome: past, present and future prospects. Microbiology and molecular biology reviews, v. 70, n. 2, p. 362-439, 2006.

HERRMANN, K. M. The shikimate pathway: early steps in the biosynthesis of aromatic compounds. The Plant Cell, v. 7, p. 907-919, 1995.

HU, Q.; DING, C.; TU, J.; WANG, X.; HAN, X.; DUAN, Y.; YU, S. Immunoproteomics analysis of whole cell bacterial proteins of Reimerella anatipestifer. Veterinary

Microbiology, v. 157, p. 428-438, 2012.

HUR, J.; LEE, J. H. Enhancement of immune responses by an attenuated Salmonella enterica Serovar Typhimurium Strain secreting an Escherichia coli heat-labile enterotoxin B subunit protein as adjuvant for a live Salmonella vaccine candidate. Clinical and Vaccine Immunology, v. 18, n. 2, p. 203-209, 2011.

JANEWAY, C.A.; MEDZHITOV, R. Innate immune recognition. Annual Review of Immunology, v. 20, p. 197-216, 2002.

JUNGBLUT, P. R. Proteome analysis of bacterial pathogens. Microbes and Infection, v. 3, p. 821-840, 2001.

JUUL - MADSEN, H.R.; VIERTLBOECK, B.; SMITH, A.L.; GÖBEL, T.W.F. Avian innate immune responses. In: DAVISON, F.; KASPERS, B.; SCHAT, K.A. Avian immunology. 1ed. Inglaterra: Elsevier, 2008. p. 129-158.

KRAH, A.; JUNGBLUT, P. R. Immunoproteomics. In: DECKER, J.; REISCHL, U. Molecular Diagnosis of Infectious Diseases. 2. ed. Totowa: Human press, 2004. p. 19-32. 
LAEMMLI, U. K. Cleavage of structural proteins during the assembly of the head of bacteriophage T4. Nature, v. 227, p. 680-685, 1970.

LI, J.; XIA, J.; TAN, C.; ZHOU, Y.; WANG, Y.; ZENG, C.; CHEN, H.; BEI, W. Evaluation of the immunogenicity and the protective efficacy of a novel identified immunogenic protein, SsPepO, of Streptococcus suis serotype 2. Vaccine, v.29, p. 6514-6519, 2011.

LYNNE, A. M.; KARIYAWASAN, S.; WANNEMUEHLER, Y.; JOHNSON, T. J.; JOHNSON, S. J.; SINHA, A. S.; LYNNE, D. K.; MOON, H. W.; JORDAN, D. M.; LOGUE, C. M.; FOLEY, S. L.; NOLAN, L. K. Recombinant Iss as a potential vaccine for avian colibacillosis, Avian Diseases, v.56, p. 192-199, 2012.

MAHAN, M. J.; SLAUCH, J. M.; MEKALANOS, J. J. Selection of bacterial virulence genes that are specifically induced in host tissues. Science, v. 259, n. 5095, p. 686-688, 1993.

MATTER, L. B.; BARBIERI, N. L.; NORDHOFF, M.; EWERS, C.; HORN, F. Avian pathogenic Escherichia coli MT78 invades chicken fibroblasts. Veterinary Microbiology, v. 148 , n. 1, p. 51-59, 2010.

MOAT, A. G.; FOSTER, J. W.; SPECTOR, M. P. Macromolecular synthesis and processing: DNA, RNA and protein synthesis. In: MOAT, A. G.; FOSTER, J. W.; SPECTOR, M. P. Microbial Physiology. 4. ed. Canada State: Wiley - Liss, 2002. p.27-100.

NATARAJAN, S.; STUCHLÍK, S.; KUKUCKOVÁ, M.; RENCZESOVÁ, V.; VÁVROVÁ, S.; BARGÁROVÁ, Z.; PÁLFFY, R.; CELEC, P.; MACOR, M.; TURNA, J. Comparative study of two forms of aro A CP4 gene in Escherichia coli. Section Cellular and Molecular Biology, v. 62, n. 3, p. 265-269, 2007.

OH, I. G., MOON, B. M., LEE, J. H., HUR, J. Induction of systemic and mucosal immune responses in mice orally administered with recombinant attenuated Salmonella expressing subunits of P fimbriae of avian pathogenic Escherichia coli. Journal of Veterinary Clinics, v. 28, p. 297-302, 2011.

PACE, F. Estudo de genes do sistema de secreção tipo VI em uma linhagem de Escherichia coli patogênica para aves (APEC). 2011.86f. Tese (Doutorado em Genética e Biologia Molecular) - Instituto de Biologia, Universidade Estadual de Campinas, São Paulo, 2011. 
PFAFF-McDONOUGH, S. J.; HORNE, S. M.; GIDDING, C. W.; EBERT, J. O.;

DOETKOTT, C.; SMITH, M. H.; NOLAN, L. K. Complement resistence-related traits among Escherichia coli isolates from apparently healthy birds and birds with colibacillosis. Avian

Diseases, v. 44, n. 1, p. 23-33, 2000.

PIECHACZEK, K.; DOBRINDT, U.; SCHIERHOM, A.; FISCHER, G. S.; HECKER, M.; HACKER, J. Influence of pathogenicity islands and the minor leuS-encoded tRNA5Leu on the proteome pattern of the uropathogenic Escherichia coli strain 536. International Journal of Medical Microbiology, v. 290, n. 1, p. 75-84, 2000.

RADHOUANI, H.; PINTO, L.; POETA, P.; IGREJAS, G. After genomics, what proteomics tools could help us understand the antimicrobial resistance of Escherichia coli? Journal of Proteomics, v. 75, n. 10, p. 2773 - 2789, 2012.

SALVADORI, M. R.; YANO, T.; CARVALHO, H. F.; PARREIRA, V. R.; GYLES, C. L. Vacuolating cytotoxin produced by avian pathogenic Escherichia coli. Avian Diseases, v. 45, p. 43-51, 2001.

SHANE, S. M. Reducing pathogenic E.coli by vaccination. World Poultry, v. 25, n. 5, 2009.

SILVEIRA, W. D.; FERREIRA, A.; BROCCHI, M.; HOLLANDA, L. M.; CASTRO, A. F. P.; YAMADA, A. T.; LANCELLOTTI, M. Biological characteristics and pathogenicity of avian Escherichia coli strains. Veterinary Microbiology, v. 85, p. 47-53, 2002.

SIMI, S. Estudo da atividade hemaglutinante de amostras de Escherichia coli enteroinvasora (EIEC). 1999. 63f. Dissertação (Mestrado em Ciências) - Instituto de Ciências Biomédicas, USP, São Paulo, 1999.

STATHOPOULOS, C.; YEN, Y. T.; TSANG, C.; CAMERON, T. Protein secretion in bacterial cells. In: EL-SHAROUD, W. Bacterial Physiology - a Molecular Approach. Berlin State: Springer, 2008. p.129-153.

THANASSI, D. G.; HULTGREN, S. J. Multiple pathways allow protein secretion across the bacterial outer membrane. Current Opinion in Cell Biology, v. 14, p. 420-430, 2000.

TJALSMA, H.; SCHAEPS, R. M. J.; SWINKELS, D. W. Immunoproteomics: From biomarker Discovery to diagnostic applications. Proteomics Clinical Applications, v. 2, p. 167-180, 2008. 
TOWBIN, H.; STAEHELIN, T.; GORDON, J. Electrophoretic transfer of proteins from polyacrilamide gels to nitrocellulose sheets: Procedure and some applications. Proceedings of the National Academy of Sciences, v. 76, n. 9, p. 4350-4354, 1979.

WONGSAWAN, K.; WONGPIA, A.; LOMTHAISONG, K.; BOONTHUM, A.; SUPJATURA V.; THRARAVICHITKUL, P. Immunoproteomic assay of Streptococcus suis serotype 2 isolated from patients. Chiang Mai Journal Science, v.37, n.1, p.134-150, 2010.

YANG, Y.; WANG, L.; YIN, J.; WANG, X.; CHENG, S.; LANG, X.; WANG, X.; QU, H.; SUN, C.; WANG, J.; ZHANG, R. Immunoproteomic analysis of Brucella melitensis and identification of a new immunogenic candidate protein for the development of brucellosis subunit vaccine. Molecular Immunology, v. 49, p. 1-10, 2011. 